\title{
Variations in diurnal and seasonal net ecosystem carbon dioxide exchange in a semiarid sandy grassland ecosystem in China's Horqin Sandy Land
}

\author{
Yayi Niu ${ }^{1,2,3,5}$, Yuqiang $\mathbf{L i}^{1,2,3}$, Hanbo Yun ${ }^{1,4,5}$, Xuyang Wang ${ }^{1,2,3}$, Xiangwen Gong ${ }^{1,2}$, Yulong Duan ${ }^{1,2,3}$, and Jing Liu ${ }^{1}$ \\ ${ }^{1}$ Northwest Institute of Eco-Environment and Resources, Chinese Academy of Sciences, Lanzhou 730000, China \\ ${ }^{2}$ University of Chinese Academy of Sciences, Beijing 100049, China \\ ${ }^{3}$ Naiman Desertification Research Station, Northwest Institute of Eco-Environment and Resources, \\ Chinese Academy of Sciences, Tongliao 028300, China \\ ${ }^{4}$ State Key Laboratory of Frozen Soil Engineering, Northwest Institute of Eco-Environment and Resources, \\ Chinese Academy of Sciences, Lanzhou, Gansu 730000, China \\ ${ }^{5}$ Center for Permafrost (CENPERM), Department of Geosciences and Natural Resource Management, \\ University of Copenhagen, 1350 Copenhagen, Denmark
}

Correspondence: Yuqiang Li (liyq@lzb.ac.cn) and Yayi Niu (niuyayi@126.com)

Received: 11 March 2020 - Discussion started: 21 April 2020

Revised: 26 October 2020 - Accepted: 3 November 2020 - Published: 15 December 2020

\begin{abstract}
Grasslands are major terrestrial ecosystems in arid and semiarid regions, and they play important roles in the regional carbon dioxide $\left(\mathrm{CO}_{2}\right)$ balance and cycles. Sandy grasslands are sensitive to climate change, yet the magnitudes, patterns, and environmental controls of their $\mathrm{CO}_{2}$ flows are poorly understood for some regions (e.g., China's Horqin Sandy Land). Here, we report the results from continuous year-round $\mathrm{CO}_{2}$ flux measurements for 5 years from a sandy grassland in China's Horqin Sandy Land. The grassland was a net $\mathrm{CO}_{2}$ source at an annual scale with a mean annual net ecosystem $\mathrm{CO}_{2}$ exchange (NEE) of $49 \pm 8 \mathrm{~g} \mathrm{C} \mathrm{m}^{-2} \mathrm{yr}^{-1}$ for the years for which a complete dataset was available $(2015,2016$, and 2018). Annual precipitation had the strongest effect on annual NEE; grassland carbon sequestration increased with the increasing precipitation since NEE depended on annual precipitation. In the spring, NEE decreased (i.e., C sequestration increased) with increasing magnitude of effective precipitation pulses, total monthly precipitation, and soil temperature $\left(T_{\text {soil }}\right)$. In the summer, NEE was dominated by the total seasonal precipitation and high precipitation pulses ( $>20 \mathrm{~mm}$ ). In the autumn, NEE increased (i.e., $\mathrm{C}$ sequestration decreased) with increasing effective precipitation pulses, $T_{\text {soil }}$, and near-surface soil water content (SWC) but decreased with increased SWC deeper in
\end{abstract}

the soil. In the winter, NEE decreased with increasing $T_{\text {soil }}$ and SWC. The sandy grassland was a net annual $\mathrm{CO}_{2}$ source because drought decreased carbon sequestration by the annual plants. Long-term observations will be necessary to reveal the true source or sink intensity and its response to environmental and biological factors.

\section{Introduction}

Arid and semiarid ecosystems cover $30 \%$ to $40 \%$ of the global terrestrial surface (Poulter et al., 2014). The extent and distribution of these areas are increasing in response to factors such as climate change, changes in wildfire frequency and intensity, and changes in land use (Asner et al., 2003; Hastings et al., 2010). These ecosystems are important because they account for $30 \%$ to $35 \%$ of terrestrial net primary productivity (Gao et al., 2012; Liu et al., 2016a) and approximately $15 \%$ of the global soil organic carbon pool (Lal, 2004; Liu et al., 2016a). Thus, these areas are important contributors to the global carbon budget due to their wide distribution (Emmerich, 2003; Nosetto et al., 2006; Poulter et al., 2014; Zhou et al., 2020), and arid and semiarid ecosystems will have significant effects on the global carbon cy- 
cle and carbon balance (Lal, 2004; Biederman et al., 2017). However, the availability of continuous, long-term measurements of water and net ecosystem $\mathrm{CO}_{2}$ exchange (NEE) has lagged in arid and semiarid ecosystems (Baldocchi et al., 2001; Hastings et al., 2010; Biederman et al., 2017). Recent research on the relationship between NEE and water in drylands has focused on the southwestern United States (Scott et al., 2015; Biederman et al., 2016, 2017) and Australia (Cleverly et al., 2016; Li et al., 2017). Compared with the more constant sink that is typically measured in mesic ecosystems, dryland ecosystems showed a wide range of carbon sink or source functions for diverse vegetation types (Biederman et al., 2017). Moreover, water availability (e.g., precipitation, evapotranspiration, soil moisture) plays a dominant role in regulating ecosystem carbon fluxes and their responses to climatic change in dryland ecosystems (Niu et al., 2008; Biederman et al., 2016; Ago et al., 2016). However, to our knowledge, there has been no report on the intra-annual and inter-annual variation in ecosystem-scale carbon fluxes in China's Horqin Sandy Land, an important dryland ecosystem in northern China. Therefore, we designed the present study to reveal how changes in water availability (e.g., total precipitation, pulse size) affect carbon fluxes in the sandy grassland ecosystems of the Horqin Sandy Land.

The Horqin Sandy Land is the largest sandy land in China, and nearly $80 \%$ of the area has been desertified ( $\mathrm{Li}$ et al., 2019). Here, we define "sandy land" as land covered by a sandy soil with a vegetation cover less than $5 \%$, which includes areas of sandy desert (Yan et al., 2003). Sandy land includes multiple overlapping ecotones, including transition zones between areas with different population pressures and between semi-humid and semiarid areas, and occurs in typical agro-pastoral ecotones. The ecological environment is fragile and extremely sensitive to climate change and human activities (Bagan et al., 2010; Zhao et al., 2015). The region's sandy grassland grows on aeolian sandy soils or areas with sandy soils as the substrate and is typical of the grassland vegetation that develops in sandy land (Munkhdalai et al., 2007). This grassland ecosystem is widespread in the Horqin Sandy Land (Zhao et al., 2007). Research has shown that the restoration of degraded sandy grassland can increase its productivity and carbon sequestration and that the ecosystem can begin to act as a carbon sink (Ruiz-Jaen and Aide, 2005; Zhao et al., 2016). However, other studies have shown that it was a carbon source (Li et al., 2012; Niu et al., 2018). Moreover, we do not yet fully understand the characteristics of NEE and its components (gross primary productivity, GPP, and ecosystem respiration, $R_{\mathrm{ec}}$ ) at an ecosystem scale particularly for sandy grassland protected by grazing exclosures, and more data are needed particularly for semiarid sandy land (Barrett, 1968; Czobel et al., 2012). Therefore, longterm monitoring of carbon fluxes, of their dynamics, and of the carbon budget of sandy grassland ecosystems will clarify the factors that determine whether sandy grassland ecosystems function as carbon sources or sinks and will fill gaps in our knowledge of the current carbon budget of the world's drylands.

Precipitation is one of the factors that most strongly affects NEE in arid and semiarid areas (Scott et al., 2015; Biederman et al., 2016). Slight changes in the amount and frequency of precipitation may trigger complex interactions among biochemical processes at the ecosystem level (Emmerich and Verdugo, 2008; Cleverly et al., 2016). Small precipitation pulses promote ecosystem carbon loss, chiefly through microbial respiration, and large precipitation pulses are necessary to elicit net carbon gain by the ecosystem's autotrophic components (Huxman et al., 2004; Schwinning and Sala, 2004; Hao et al., 2010). To better understand the effects of precipitation on NEE, we asked the following question: is there a threshold of "effective precipitation" that determines whether ecosystem carbon fluxes will lead to net sequestration or net emission in sandy grasslands?

Precipitation is characterized by discrete events in arid and semiarid regions with high variability in the amount, duration, and frequency of precipitation at intra-annual (e.g., seasonal) and inter-annual scales (Hao et al., 2010; Ponce Campos et al., 2013). These discrete and largely unpredictable events may lead to the pulsed availability of soil water and nutrients with both spatial and temporal variation (Noy-Meir, 1973; Zhao and Liu, 2011). The responses of photosynthesis and respiration to precipitation are seasonally specific because of differences in the depth of soil water infiltration and because these processes differ in their sensitivity to temperature (Li and Zhou, 2012). Spring and autumn precipitation are important controls on the beginning and end dates of the growing season, so the ability of these events to change carbon accumulation or emission should not be ignored, especially in semiarid and arid regions (Prevéy et al., 2014; Shen et al., 2015). This is particularly true when relatively low temperatures limit soil microbial respiration during certain periods (Knorr et al., 2005). Summer precipitation tends to comprise a relatively large total amount, provided by relatively large pulses, and can infiltrate the soil to a depth where it becomes plant-available and can trigger net photosynthesis, but a combination of high temperatures and high soil moisture also stimulates respiration by soil microbes (Huxman et al., 2004; Chen et al., 2009; Liu et al., 2016a; Zhou et al., 2020). The total amount and pulse size of summer precipitation may therefore play an important role in regulating inter-annual variations in the ecosystem carbon balance (Chen et al., 2009; Scott et al., 2009; Wu et al., 2012). Understanding the consequences of climate change, and particularly the changes in precipitation patterns and their effect on soil water regimes, may be critical for developing strategies to preserve or restore these sandy grasslands.

In this paper, we present the results from continuous (14 September 2014 to 31 December 2018) in situ monitoring of $\mathrm{CO}_{2}$ fluxes (NEE, GPP, and $R_{\mathrm{ec}}$ ) in the Horqin Sandy Land's sandy grassland using the eddy covariance technique. We quantify the $\mathrm{CO}_{2}$ fluxes over different timescales and 


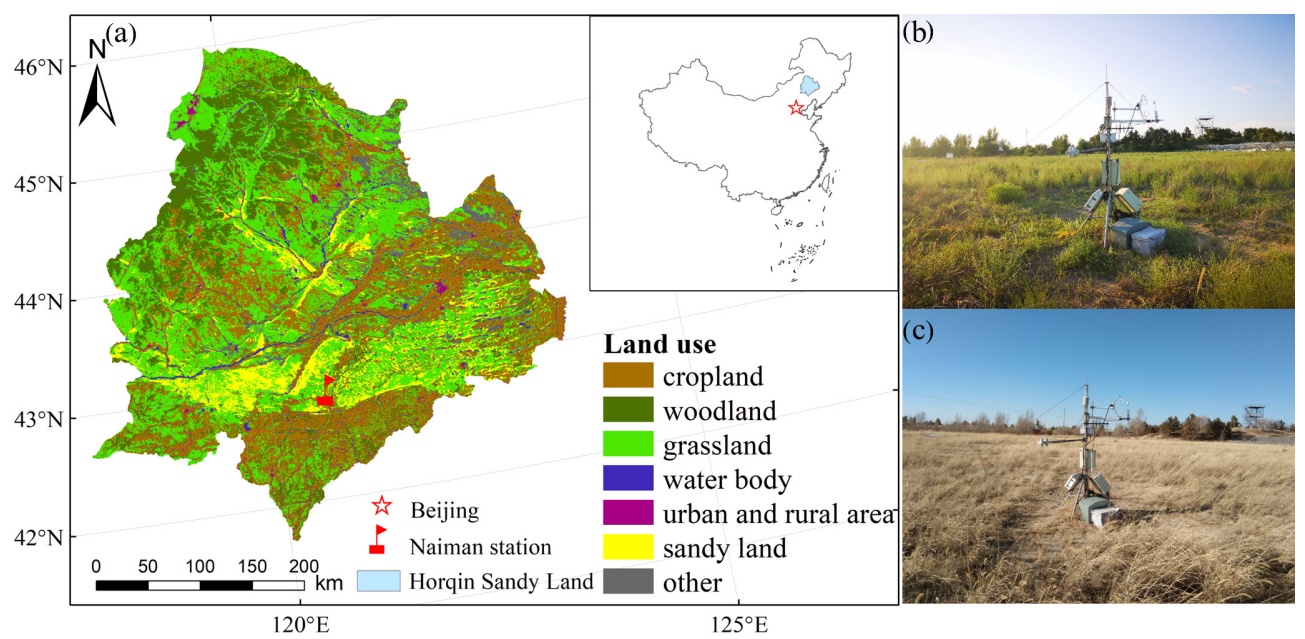

Figure 1. (a) Locations of the Horqin Sandy Land and the Naiman station. Panels (b) and (c) are photos of the eddy covariance site at the Naiman station during the growing and dormant seasons, respectively.

identify the factors that control the ecosystem's carbon balance. We had the following goals. (1) To quantify the annual, seasonal, and diurnal variations in NEE, GPP, and $R_{\mathrm{ec}}$, we hypothesized that the sandy grassland is a carbon source at the ecosystem scale because the sandy grassland is dominated by annual plants that are vulnerable to drought $(\mathrm{Li}$ et al., 2016; Kang et al., 2018) and that GPP would depend strongly on precipitation in this ecosystem, so that years with low precipitation would cause the ecosystem to become a net carbon source. (2) To determine whether there is a threshold of effective precipitation in this sandy grassland, based on the response thresholds of shrubs and herbs to precipitation in arid and semiarid areas (Hao et al., 2010; Zhou et al., 2020), we hypothesized that an effective precipitation threshold would exist at around $5 \mathrm{~mm}$ and that precipitation greater than this threshold would alter soil moisture in deeper layers and thereby affect carbon fluxes in the sandy grassland ecosystem. (3) To explore the effects of changes in total precipitation and pulse size on NEE, GPP, and $R_{\mathrm{ec}}$, we also hypothesized that spring, summer, and autumn precipitation would have different impacts on the ecosystem $\mathrm{CO}_{2}$ exchange through their differential effects on plant photosynthesis and soil respiration (Scott et al., 2009).

\section{Materials and methods}

\subsection{Experimental site}

Our study was conducted in a sandy grassland in the southern part of the Horqin Sandy Land, Inner Mongolia, China, at the Naiman Desertification Research Station of the Chinese Academy of Sciences $\left(42^{\circ} 55^{\prime} \mathrm{N}, 120^{\circ} 42^{\prime} \mathrm{E}\right)$ (Fig. 1a). The terrain is flat, and it evolved from the reclamation of sandy grassland for agriculture that led to severe desertification, after which cultivation was abandoned and grazing exclosures were established to allow the natural recovery of the vegetation starting in 1985 (Zhao et al., 2007). Thus, the grassland had been recovering naturally for nearly 30 years when our study began. At an elevation of $377 \mathrm{~m}$ above sea level (a.s.l.), the study area has a continental semiarid monsoon temperate climate regime. The mean annual temperature is $6.8^{\circ} \mathrm{C}$, with mean monthly temperatures ranging from $-9.63^{\circ} \mathrm{C}$ in January to $24.58^{\circ} \mathrm{C}$ in July. Average annual precipitation is approximately $360 \mathrm{~mm}$, with about $70 \%$ of the precipitation occurring during the growing season between June and August. Annual mean potential evaporation is approximately $1973 \mathrm{~mm}$. The annual frost-free period is 130 to $150 \mathrm{~d}$. The most common soil type in the study region is a sandy chestnut soil, but most of the soil has been degraded by a combination of climate change and anthropogenic activity (unsustainable grazing or agriculture) into an aeolian sandy soil under the action of wind erosion (Zhao et al., 2007) with coarse sand, fine sand, and clay and silt contents of $92.7 \%, 3.3 \%$, and $4.0 \%$, respectively, in the topsoil to a depth of $20 \mathrm{~cm}$. The contents of soil organic carbon and total nitrogen were 1.27 and $0.21 \mathrm{~g} \mathrm{~kg}^{-1}$, respectively. Vegetation cover in the study area ranged from $50 \%$ to $70 \%$. The dominant plant species were annual herbs, including Artemisia scoparia, Setaria viridis, Salsola collina, and Corispermum hyssopifolium (Niu et al., 2018).

\subsection{Micrometeorological measurements}

Along with the flux measurements obtained by the eddy covariance equipment (see the next section for details), we measured standard meteorological and soil parameters continuously with an array of sensors. A propeller anemometer was installed at the top of the meteorological tower to measure the wind speed and direction. Net solar radiation $\left(R_{\mathrm{n}}, \mathrm{W} \mathrm{m}^{-2}\right)$ was measured by a four-component radiometer 
(CNR-1, Kipp and Zonen, Delft, the Netherlands) installed $1 \mathrm{~m}$ above the ground. The air temperature $\left(T_{\text {air }},{ }^{\circ} \mathrm{C}\right)$ and relative humidity (\%) instrument (HMP45C, Vaisala Inc., Helsinki, Finland) was mounted $2 \mathrm{~m}$ above the ground to measure the $T_{\text {air }}$, relative humidity, and atmospheric pressure $(\mathrm{kPa})$. Precipitation $(\mathrm{mm})$ measurements were obtained from a meteorological station $400 \mathrm{~m}$ from the study site. Total daily precipitation was treated as a single event rather than as a series of events.

We installed five CS109 temperature probes (Campbell Scientific, Logan, UT, USA) and five CS616 moisture probes (Campbell Scientific) in the soil at depths of 10, 20, 30, 40, and $50 \mathrm{~cm}$ to measure soil temperature $\left(T_{\text {soil }},{ }^{\circ} \mathrm{C}\right)$ and soil water content (SWC, \%). Two self-calibrating HFP01 soil heat flux (SHF, $\mathrm{W} \mathrm{m}^{-2}$ ) sensors (Hukseflux, Delft, the Netherlands) were buried 5 and $10 \mathrm{~cm}$ below the ground to obtain the SHF data that were used to calculate the energy closure. All of the environmental parameters were measured simultaneously with the eddy covariance measurements, and all data were recorded as 30 min mean values with a CR3000 datalogger (Campbell Scientific).

\subsection{Eddy covariance observations}

An eddy covariance flux tower ( $2.0 \mathrm{~m}$ high) was installed at the center of the observation field (Fig. $1 b$ and c). We have continuously monitored $\mathrm{CO}_{2}$, water, and heat fluxes at the tower using the eddy covariance system since late 2014 . The site was flat and comprised of homogeneous vegetation. The upwind fetch was about $200 \mathrm{~m}$ under unstable atmospheric conditions, which was greater than the flux footprint (Schmid, 1997; Xu and Baldocchi, 2004). The eddy covariance system consisted of an LI-7500 infrared gas analyzer (Li-Cor Inc., Lincoln, NE, USA), with an accuracy of $1 \%$ or better recording measurements at a frequency of $10 \mathrm{~Hz}$, and a CSAT3 three-dimensional ultrasonic anemometer (Campbell Scientific), with an accuracy of $2 \%$ or better recording measurements at a frequency of $10 \mathrm{~Hz}$. Raw $10 \mathrm{~Hz}$ data were recorded by a CR3000 datalogger. The operation, calibration, and maintenance of the eddy covariance system followed the manufacturers' standard procedures. The LI-7500 was calibrated every 6 months for $\mathrm{CO}_{2}$, water vapour, and dew point values using calibration gases and dew point generator measurements supported by the China Land-Atmosphere Coordinated Observation System (Yun et al., 2018). We cleaned the mirror of the LI-7500 every $15 \mathrm{~d}$ to maintain the automatic gain control value below its threshold (55 to 65). All of the instruments were powered by solar panels connected to a battery.

\subsection{Data quality and gap-filling method}

We used the EddyPro 6.2.0 software (Li-Cor) to process the $10 \mathrm{~Hz}$ raw eddy covariance data. Processing (based on the manufacturer's recommendations and previous research) included spike removal, lag correction, secondary coordinate rotation, Webb-Pearman-Leuning correction, sonic virtual temperature conversion, and infrared gas analyzer selfheating correction during the coldest days (with temperatures $<-10^{\circ} \mathrm{C}$ ) (Webb et al., 1980; Burba et al., 2008). We used the data processing method of Lee et al. (2004) to process the 30 min mean raw flux measurements to ensure their quality. Processed data were further corrected for weather effects and sensor uncertainty using the following procedure: (1) we removed data gathered during precipitation events and during periods of sensor maintenance or malfunction; (2) we excluded unrealistic $\mathrm{CO}_{2}$ flux data (values outside the range of -45.45 to $45.45 \mu \mathrm{molCO}_{2} \mathrm{~m}^{-2} \mathrm{~s}^{-1}$ ); and (3) we rejected data collected during periods of insufficient turbulent mixing using a friction-velocity filter $\left(u^{*}<0.1 \mathrm{~m} \mathrm{~s}^{-1}\right)$ for data collected at night (Reichstein et al., 2005; Scott et al., 2009). This screening resulted in the rejection of $20 \%$ to $30 \%$ of the flux data, depending on the period.

We used several strategies to compensate for missing data. We used linear interpolation to fill gaps that were shorter than $2 \mathrm{~h}$. For longer gaps, NEE was classified based on the $R_{\mathrm{n}}$ as the daytime exchange $\left(\mathrm{NEE}_{\text {day }} ; R_{\mathrm{n}} \geq 1 \mathrm{~W} \mathrm{~m}^{-2}\right)$ or the nighttime exchange ( $\mathrm{NEE}_{\text {night }} ; R_{\mathrm{n}}<1 \mathrm{Wm}^{-2}$ ). We handled gaps in the $\mathrm{NEE}_{\text {day }}$ using the mean diurnal variation with a $7 \mathrm{~d}$ window centered on the day with missing data (Falge et al., 2001), and we handled gaps in the $\mathrm{NEE}_{\text {night }}$ using Eq. (1), with the parameter values calculated with a $7 \mathrm{~d}$ moving window centered on the day with missing data using version 22 of the SPSS software (IBM, Armonk, NY, USA) (Lloyd and Taylor, 1994; Reichstein et al., 2005):

$\mathrm{NEE}_{\text {night }}=R_{0} \exp \left(b T_{10}\right)$,

where $R_{0}$ is the base ecosystem respiration rate when the soil temperature is $0^{\circ} \mathrm{C}, b$ is an empirically determined coefficient, and $T_{10}$ is the soil temperature at a depth of $10 \mathrm{~cm}$. Daytime ecosystem respiration can be estimated by extrapolation from the parameterization derived from Eq. (1). We did not attempt to fill gaps longer than $7 \mathrm{~d}$ and treated those gaps as missing data. Gross primary productivity (GPP) was obtained as follows:

$\mathrm{GPP}=R_{\mathrm{ec}}-\mathrm{NEE}$.

We used the standard sign convention for NEE, with NEE $>0$ indicating a net loss of $\mathrm{CO}_{2}$ to the atmosphere (source) and NEE $<0$ indicating net $\mathrm{CO}_{2}$ uptake by the ecosystem (sink).

We evaluated the data quality based on the degree of energy closure (sensible heat + latent heat - net radiation - soil heat flux). The energy closure values for the sandy grassland from 2015 to 2018 were $87 \%, 83 \%, 58 \%$, and $86 \%$, respectively (Fig. S1 in the Supplement). 


\subsection{Statistical analyses}

We performed correlation analysis (Pearson's $r$ ) and regression analysis using the SPSS software. Unless otherwise noted, we defined statistical significance at $p<0.05$. Pearson's $r$ was applied to confirm the strength of the relationships between parameters. Before regression analysis, we tested for collinearity (using a variance inflation factor of $0<\mathrm{VIF}<10)$ using the Kaiser-Meyer-Olkin $(\mathrm{KMO})$ test and Bartlett's sphericity test. Collinearity was used to repartition the $T_{\text {soil }}$ and SWC data. We considered KMO values $>0.50$ and $p<0.05$ for Bartlett's sphericity test to indicate acceptable data (Hair et al., 2005). The KMO value ranged from 0.52 to 0.78 and $p<0.001$ for all Bartlett's sphericity test results for our data.

\section{Results}

\subsection{Meteorological conditions}

Figures S2 to S5 in the Supplement show the diurnal and seasonal variation in the meteorological factors during the observation period. The mean daily $T_{\text {air }}, R_{\mathrm{n}}$, and $T_{\text {soil }}$ at depths of $10,20,30,40$, and $50 \mathrm{~cm}$ showed unimodal seasonal variations in all 4 years. These parameters were therefore largely stable and did not differ greatly between years except for the precipitation and SWC at all depths; precipitation and SWC were lower in 2014 and 2015 than in the other years (Fig. S5b). Thus, precipitation and SWC were the main factors that influenced NEE, and we focused on them in our analysis. The annual precipitation totaled $208 \mathrm{~mm}$ in 2015, $277 \mathrm{~mm}$ in 2016, $313 \mathrm{~mm}$ in 2017, and $351 \mathrm{~mm}$ in 2018 (Fig. S5b). Zhao and Liu (2010) showed that precipitation less than $5 \mathrm{~mm}$ in arid and semiarid areas changes SWC primarily in the near-surface soil and that precipitation events greater than $5 \mathrm{~mm}$ can effectively supplement root layer moisture at greater depths; these larger pulses are therefore called "effective precipitation". Our results (Fig. 2) were consistent with this view.

The essence of effective precipitation is that precipitation enters the soil below the surface layer and becomes part of the soil water; that soil water is then used either directly or indirectly by the vegetation and has an impact on the ecosystem's carbon absorption and emission processes (Joseph Turk et al., 2012). Therefore, we studied the influence of precipitation on NEE and its components in each season from the perspective of SWC. The climate was drier in 2015-2017 than in a normal year. Based on the mean annual precipitation of $360 \mathrm{~mm}$ from 1960 to 2014, precipitation was $58 \%$ of this total in 2015 versus $77 \%$ in 2016 and $87 \%$ in 2017, whereas 2018 was close to a normal year. The variation in soil water content was related to precipitation patterns. During the spring (March-April-May), precipitation was relatively abundant with a mean total spring precip- itation of about $42 \mathrm{~mm}$, which accounted for $12 \%$ to $20 \%$ of the total annual precipitation. The majority of the precipitation (56\% to $95 \%$ ) occurred in the summer (June-JulyAugust) with a mean precipitation of about $197 \mathrm{~mm}$. The autumn (September-October-November) precipitation was similar to that in spring with a mean total autumn precipitation of about $49 \mathrm{~mm}$, which accounted for $14 \%$ to $24 \%$ of the annual total. During the winter (December-JanuaryFebruary), the mean total precipitation of $0.6 \mathrm{~mm}$ accounted for less than $1 \%$ of the annual total and was largely stable with small differences among the years.

\subsection{Annual, seasonal, and diurnal variability in NEE, GPP, and $R_{\text {ec }}$}

We also observed clear seasonal variations in daily mean NEE, GPP, and $R_{\mathrm{ec}}$ from 2014 to 2018 (Fig. 3). Our results suggest that the sandy grassland was a net $\mathrm{CO}_{2}$ source at an annual scale with an annual mean NEE, GPP, and $R_{\mathrm{ec}}$ of $49 \pm 8,303 \pm 29$, and $352 \pm 21 \mathrm{~g} \mathrm{Cm}^{-2} \mathrm{yr}^{-1}$, respectively, in the years for which a complete dataset was available (2015, 2016, and 2018) (Fig. 3f). We omitted 2017 from this calculation because of large gaps in the data, as described below. NEE ranged from $35 \mathrm{~g} \mathrm{Cm}^{-2} \mathrm{yr}^{-1}$ in 2018 to $63 \mathrm{~g} \mathrm{Cm}^{-2} \mathrm{yr}^{-1}$ in 2015 , whereas GPP ranged from $256 \mathrm{~g} \mathrm{Cm}^{-2} \mathrm{yr}^{-1}$ in 2015 to $356 \mathrm{~g} \mathrm{Cm}^{-2} \mathrm{yr}^{-1}$ in 2018 , and $R_{\mathrm{ec}}$ ranged from $319 \mathrm{~g} \mathrm{Cm}^{-2} \mathrm{yr}^{-1}$ in 2015 to $391 \mathrm{~g} \mathrm{C} \mathrm{m}^{-2} \mathrm{yr}^{-1}$ in 2018 . From 15 September to $23 \mathrm{De}$ cember 2014, we measured a cumulative carbon release of $47 \mathrm{~g} \mathrm{Cm}^{-2}$ with a cumulative GPP and $R_{\mathrm{ec}}$ of 25 and $72 \mathrm{~g} \mathrm{C} \mathrm{m}^{-2}$, respectively. From 15 February to 26 April 2017 and from 14 October to 6 November 2017, approximately 3 months of data were missing due to instrument maintenance and calibration, and the cumulative NEE, GPP, and $R_{\mathrm{ec}}$ were 64,274 , and $338 \mathrm{~g} \mathrm{Cm}^{-2}$, respectively, for the remaining 9 months of the year. Note that the periods covered by the data are therefore not identical.

Figures 4 and 5 show the seasonal NEE, GPP, and $R_{\mathrm{ec}}$ and their diurnal cycles, respectively. In the spring, the sandy grassland was an atmospheric $\mathrm{CO}_{2}$ source in all years, with NEE, GPP, and $R_{\mathrm{ec}}$ averaging $0.14 \pm 0.04,0.60 \pm 0.06$, and $0.74 \pm 0.02 \mathrm{~g} \mathrm{C} \mathrm{m}^{-2} \mathrm{~d}^{-1}$, respectively (Fig. 4a). The diurnal NEE cycle was characterized by a single peak, and between 07:30 and 16:30, the ecosystem showed net $\mathrm{CO}_{2}$ absorption (Fig. 5a); the rest of the day was characterized by weak $\mathrm{CO}_{2}$ emission. Note that although all times in China are reported as Beijing time, the study site was not sufficiently far east of Beijing for this to affect the physiological meaning of these times. The average diurnal GPP was also characterized by a single peak, with positive values from around 05:00 to around 19:30, and the diurnal $R_{\mathrm{ec}}$ was characterized by an approximately horizontal line at about $0.75 \mu \mathrm{mol} \mathrm{m}^{-2} \mathrm{~s}^{-1}$ but with slightly higher respiration during the day.

In summer, the sandy grassland was a $\mathrm{CO}_{2}$ sink in all years, with NEE, GPP, and $R_{\mathrm{ec}}$ averaging $-0.66 \pm 0.08$, 

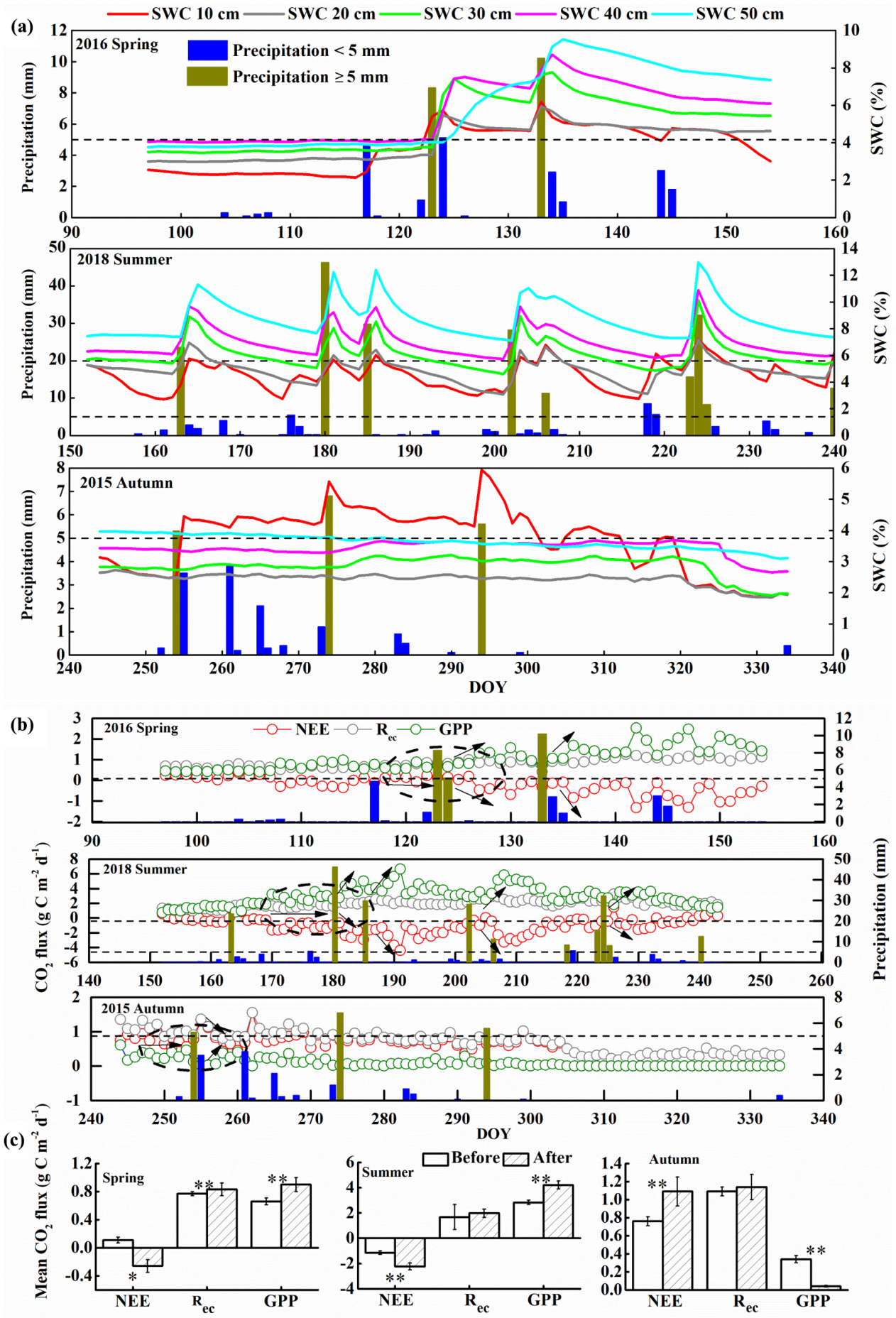

Figure 2. (a) Changes in soil water content (SWC) at depths of 10, 20, 30, 40, and $50 \mathrm{~cm}$ that resulted from precipitation events in spring, summer, and autumn (DOY, day of year). Precipitation $\geq 5 \mathrm{~mm}$ represents effective precipitation. (b) Daily net ecosystem exchange (NEE), respiration $\left(R_{\mathrm{ec}}\right)$, and gross primary productivity (GPP) responses to precipitation pulses during the spring of 2016, summer of 2018, and autumn of 2015. The black arrows indicate the trends for carbon fluxes after effective precipitation. (c) Comparison of the mean carbon fluxes before and after effective precipitation pulses based on daily data. We chose the effective precipitation pulses that had no precipitation for $7 \mathrm{~d}$ after this precipitation (i.e., the period represented by the dashed lines circled in (b). "Before" values represent the average carbon fluxes for $7 \mathrm{~d}$ before the precipitation pulse, and "after" values represent the average carbon fluxes for 3 to $5 \mathrm{~d}$ after the precipitation pulse; the error bars represent standard errors $(* *, p<0.01 ; *, p<0.05)$. The horizontal dashed lines in (b) and (c) indicate $5 \mathrm{~mm}$ of precipitation in spring and autumn and 5 and $20 \mathrm{~mm}$ in summer. 

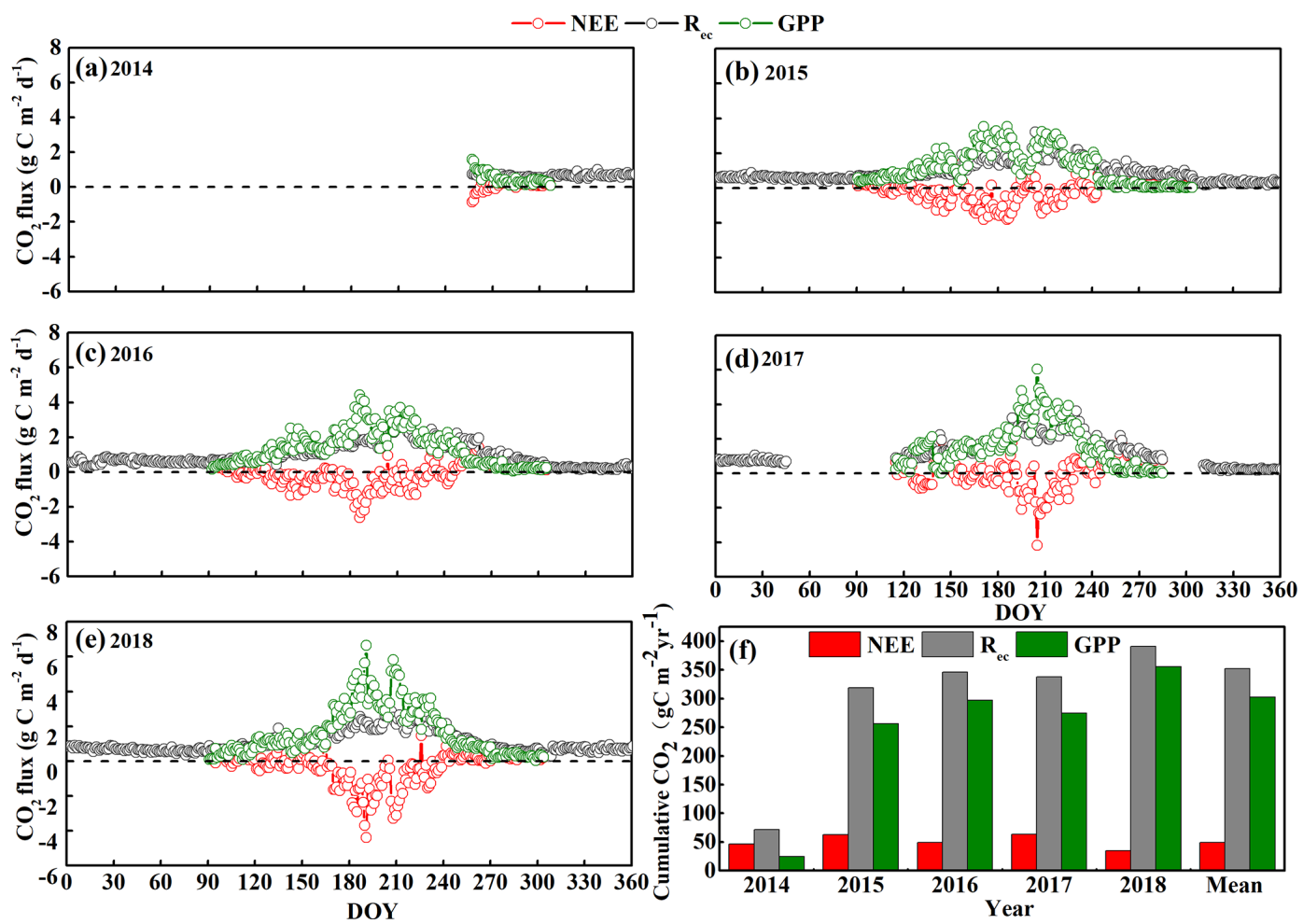

Figure 3. Seasonal and inter-annual variation in the daily average net ecosystem $\mathrm{CO}_{2}$ exchange (NEE), gross primary productivity (GPP), and ecosystem respiration $\left(R_{\mathrm{ec}}\right)$ from (a-e) 2014 to 2018 by day of year (DOY). (f) Annual cumulative NEE, GPP, and $R_{\mathrm{ec}}$ from 2014 to 2018. Positive NEE values indicate net $\mathrm{CO}_{2}$ release, whereas negative values indicate net $\mathrm{CO}_{2}$ uptake by the ecosystem. Note that the initial measurements were from 15 September to 23 December 2014, so no data are available for the first part of 2014.

$2.45 \pm 0.09$, and $1.79 \pm 0.04 \mathrm{~g} \mathrm{C} \mathrm{m}^{-2} \mathrm{~d}^{-1}$, respectively (Fig. 4b). The diurnal cycles of NEE and GPP were also characterized by a single peak, and the ecosystem $\mathrm{CO}_{2}$ uptake reached its peak between around 10:30 and 12:00 (Fig. 5b). NEE decreased (C sequestration increased) with increasing light intensity during the day, reached its peak value around noon, then increased until sunset when the ecosystem changed from net carbon absorption to net carbon release. The diurnal $R_{\mathrm{ec}}$ pattern was the opposite of the spring pattern, and the peak $R_{\mathrm{ec}}$ occurred at night.

In autumn, the sandy grassland was a net source of atmospheric $\mathrm{CO}_{2}$ in all years, with NEE, GPP, and $R_{\mathrm{ec}}$ averaging $0.50 \pm 0.03,0.26 \pm 0.03$, and $0.76 \pm 0.04 \mathrm{~g} \mathrm{C} \mathrm{m}^{-2} \mathrm{~d}^{-1}$, respectively (Fig. 4c). The diurnal dynamics of NEE, GPP, and $R_{\mathrm{ec}}$ in autumn (Fig. 5c) were similar to those in spring (Fig. 5a), but the magnitudes of NEE and GPP in autumn were lower than in the spring. The diurnal $R_{\mathrm{ec}}$ was similar to the value in the spring at about $0.73 \mu \mathrm{molm}^{-2} \mathrm{~s}^{-1}$ and with higher values during the day.

In winter, the grassland ecosystem functioned as a net $\mathrm{CO}_{2}$ source in all years, with an average seasonal NEE of $0.59 \pm 0.02 \mathrm{~g} \mathrm{Cm}^{-2} \mathrm{~d}^{-1}$ (Fig. 4d). It should also be noted that since the investigation started on 14 September 2014 and ended on 31 December 2018, the 2017 to 2018 winter was only about one-third of the usual length (i.e., it did not include data from January and February 2019). The diurnal dynamics of the winter NEE differed from the other seasons (Fig. 5d) with a minimum release value of $0.36 \mu \mathrm{mol} \mathrm{m}^{-2} \mathrm{~s}^{-1}$ and with two emission peaks at $0.78 \mu \mathrm{mol} \mathrm{m}^{-2} \mathrm{~s}^{-1}$ (08:00) and $0.85 \mu \mathrm{mol} \mathrm{m}^{-2} \mathrm{~s}^{-1}$ (16:30).

\subsection{Responses of NEE, GPP, and $R_{\mathrm{ec}}$ to changes in environmental factors}

At an annual scale, the major environment difference among the years with a complete dataset $(2015,2016$, and 2018) was the amount of precipitation (Fig. S5b). We analyzed the relationship between precipitation and the annual NEE, GPP, and $R_{\text {ec }}$ in 2015, 2016, and 2018 (Fig. 6). We found that GPP and $R_{\text {ec }}$ increased significantly with increasing annual precipitation, whereas NEE decreased significantly with increasing annual precipitation, indicating that the ecosystem's carbon sequestration capacity increased with increasing precipitation. Taken together, these results indicated different magnitudes and directions of response of the three parameters to annual precipitation.

The temperature, precipitation, and $\mathrm{CO}_{2}$ fluxes (NEE, GPP, and $R_{\text {ec }}$ ) were relatively stable in winter (Figs. $4 \mathrm{~d}$ and S5). We therefore focused on the relationships between NEE, its components, and the associated environmental fac- 

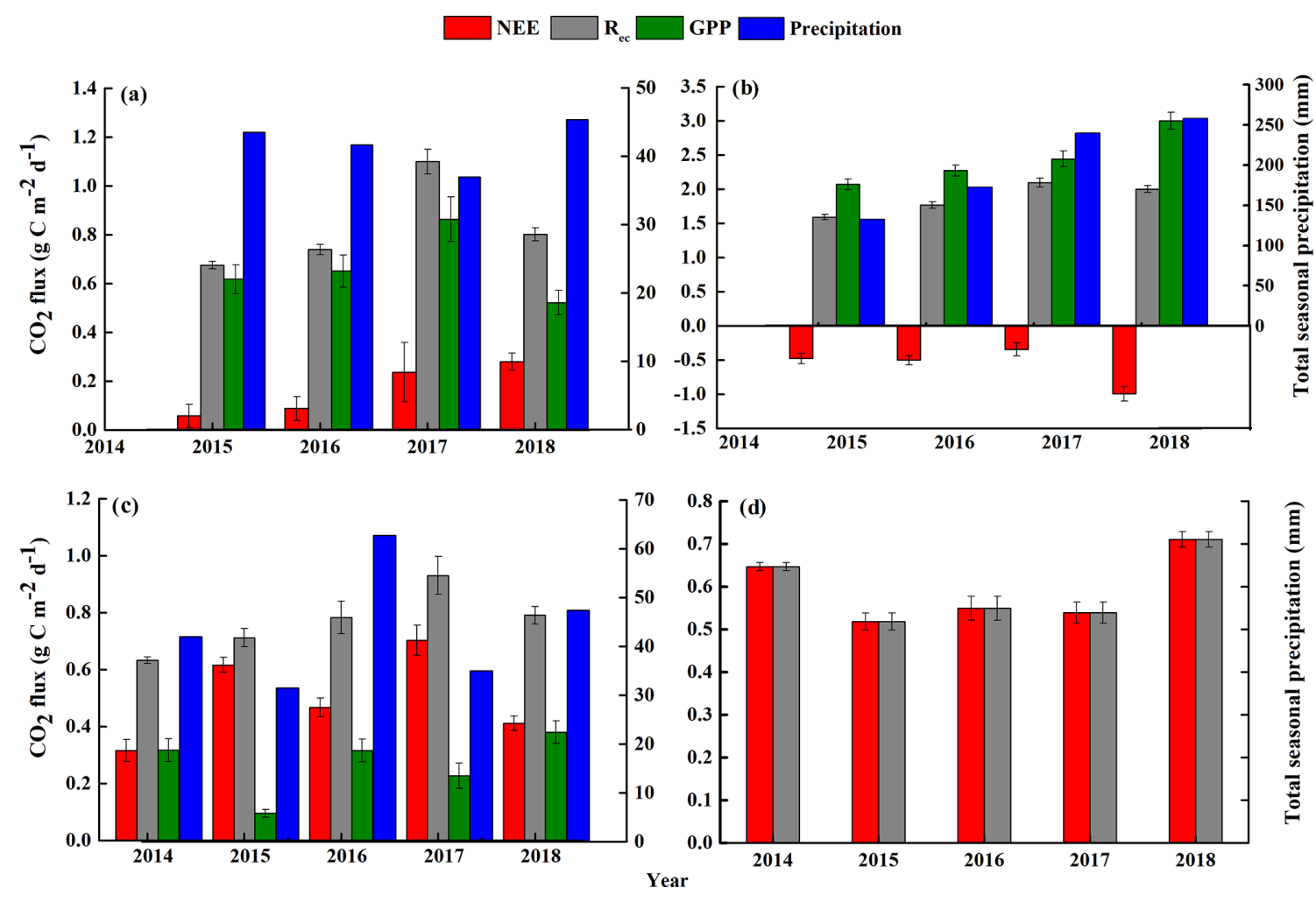

Figure 4. Seasonal mean net ecosystem $\mathrm{CO}_{2}$ exchange (NEE), gross primary productivity (GPP), and ecosystem respiration $\left(R_{\mathrm{ec}}\right)$ and the total seasonal precipitation from 2014 to 2018: (a) spring (March-April-May), (b) summer (June-July-August), (c) autumn (SeptemberOctober-November), and (d) winter (December-January-February). Note that the $y$-axis scales differ greatly between the graphs, and that the initial measurements were from 15 September to 23 December 2014, so no data are available for the first part of 2014. The final measurements were obtained on 31 December 2018, so the winter period from 2017 to 2018 was only about one-third of the usual length (i.e., it did not include data from January and February 2019). The error bars for the mean carbon fluxes represent standard errors.

tors in the other three seasons (Figs. 4 and 7). In the spring, the monthly precipitation was significantly negatively correlated with NEE but significantly positively correlated with GPP and $R_{\mathrm{ec}}$, and GPP responded more strongly than $R_{\mathrm{ec}}$ to precipitation: slope $\mathrm{GPP}_{\mathrm{GP}}(0.88)>$ slope $_{\text {Rec }}(0.43)$ (Fig. 7). That is, plants were affected more strongly than soil microbes by changes in water availability. In summer, the monthly precipitation was not significantly correlated with NEE, GPP, and $R_{\text {ec }}$ (Fig. 7). However, the trends for seasonal average NEE, GPP, and $R_{\mathrm{ec}}$ were similar to that for total seasonal precipitation in different years. With increasing precipitation, GPP and $R_{\mathrm{ec}}$ increased, whereas NEE decreased (Fig. 4b), and the summer precipitation therefore increased the carbon sequestration capacity of the ecosystem. In autumn, the monthly precipitation was significantly positively correlated with GPP and $R_{\mathrm{ec}}$ with a similar strength of the response to precipitation: slope $\operatorname{Rec}(0.75)$ and slope ${ }_{\mathrm{GPP}}(0.72)$ (Fig. 7). Therefore, NEE was not significantly correlated with monthly precipitation (i.e., because the responses for GPP and $R_{\text {ec }}$ offset each other).

At a daily scale, the responses of NEE, $R_{\mathrm{ec}}$, and GPP to precipitation pulses $<5 \mathrm{~mm}$ were minimal (Fig. 2 b; e.g., day of year (DOY) 104 and 107 in spring 2016, DOY 176 and 219 in summer 2018, DOY 283 and 284 in autumn 2015), whereas a precipitation pulse $>5 \mathrm{~mm}$ led to a large response of NEE, $R_{\text {ec }}$, and GPP (Fig. 2b; e.g., DOY 123 and 133 in spring 2016, DOY 180 and 185 in summer 2018, DOY 254 in autumn 2015). This confirms that effective precipitation resulted from a precipitation pulse $>5 \mathrm{~mm}$. In spring, the effective precipitation pulses significantly increased the magnitude of $R_{\mathrm{ec}}$ and GPP as the size of the precipitation pulse increased, and this triggered a significant decrease in NEE (i.e., increased C sequestration; Fig. 2c). In summer, the effective precipitation pulses triggered small changes in NEE, GPP, and $R_{\mathrm{ec}}$, which rapidly returned to their pre-pulse values (Fig. 2b; e.g., DOY 218 in summer 2018). This may have been because of the high temperature and faster evaporation in summer. However, the high precipitation pulses $(>20 \mathrm{~mm}$ ) significantly increased GPP and led to significant decreases in NEE (Fig. 2b and c; e.g., DOY 180, 185, 202, and 224 in summer 2018). In autumn, the effective precipitation pulses significantly decreased GPP and increased NEE (i.e., less $\mathrm{C}$ sequestration; Fig. 2c). 

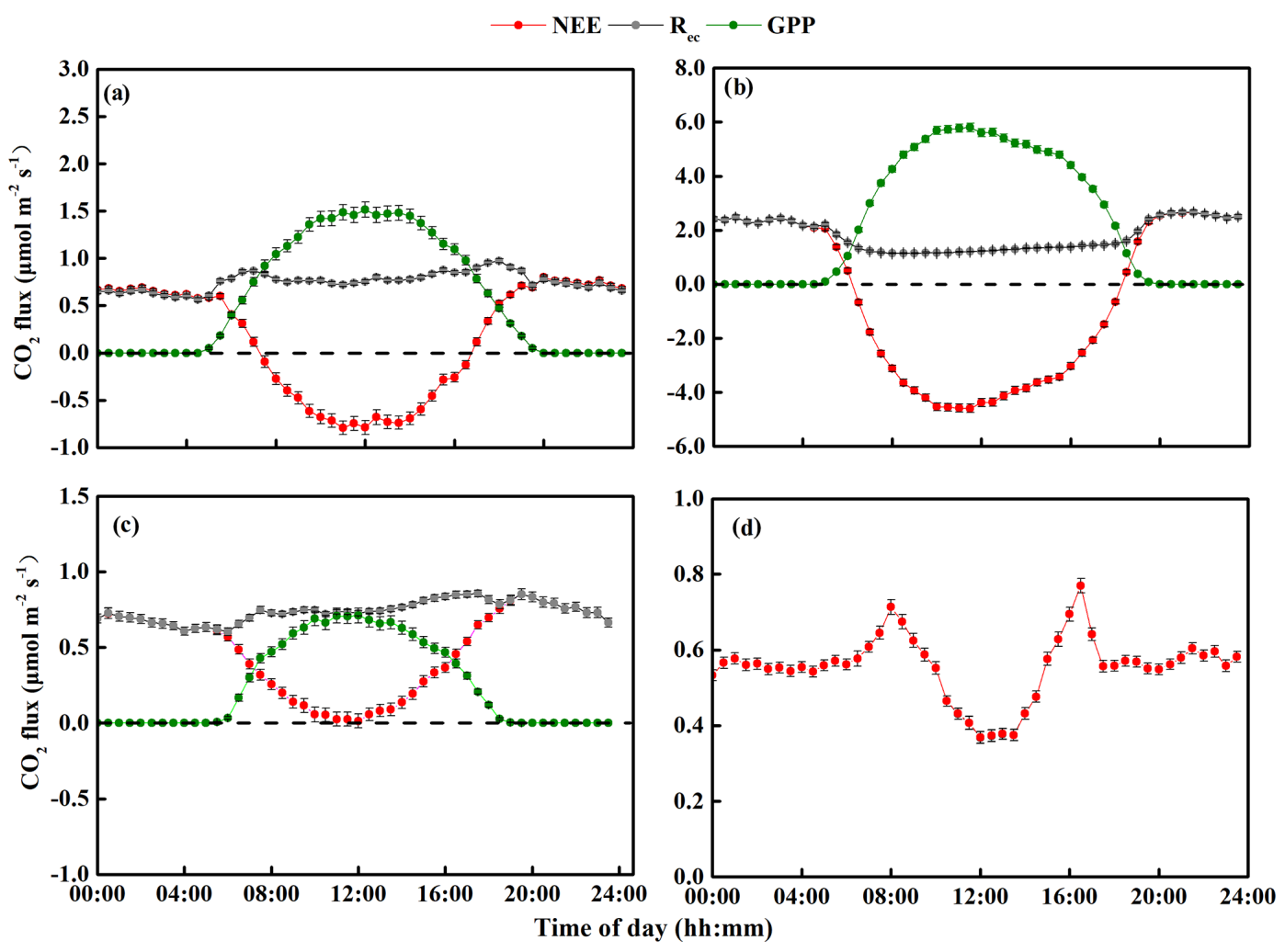

Figure 5. Diurnal changes in mean net ecosystem $\mathrm{CO}_{2}$ exchange (NEE), gross primary productivity (GPP), and ecosystem respiration $\left(R_{\mathrm{ec}}\right)$ from 2014 to 2018: (a) spring (March-April-May), (b) summer (June-July-August), (c) autumn (September-October-November), and (d) winter (December-January-February). Note that the $y$-axis scales differ greatly between the graphs and that the initial measurements were from 15 September to 23 December 2014, so the spring and summer data in this year do not include the period before 15 September. The final measurements were obtained on 31 December 2018, so the winter period from 2017 to 2018 was only about one-third of the usual length (i.e., it did not include data from January and February 2019). The error bars for the mean carbon fluxes represent standard errors.

We also calculated the correlations between the three $\mathrm{CO}_{2}$ fluxes (NEE, $R_{\mathrm{ec}}$, and GPP) and both SWC and $T_{\text {soil }}$ and then performed regression analysis to further understand their relationship with SWC at depths of 10, 20,30, 40, and $50 \mathrm{~cm}$ in the spring, summer, and autumn periods (Table S1 in the Supplement, Fig. 8). In spring, NEE was significantly negatively correlated with $T_{\text {soil }}$ from 0 to $50 \mathrm{~cm}$ with SWC from 10 to $50 \mathrm{~cm}$ and with $\mathrm{SWC}$ from 0 to $10 \mathrm{~cm}$. GPP and $R_{\mathrm{ec}}$ were significantly positively correlated with these environmental factors. In summer, NEE was significantly negatively correlated with $T_{\text {soil }}$ from 0 to $50 \mathrm{~cm}$ and with SWC from 40 to $50 \mathrm{~cm}$ but was not significantly correlated with SWC from 0 to $10 \mathrm{~cm}$. GPP and $R_{\mathrm{ec}}$ were significantly positively correlated with $T_{\text {soil }}$ from 0 to $50 \mathrm{~cm}, \mathrm{SWC}$ from 10 to $50 \mathrm{~cm}$, and SWC from 0 to $10 \mathrm{~cm}$. $T_{\text {soil }}$ from 0 to $50 \mathrm{~cm}$ had a smaller impact on NEE, GPP, and $R_{\mathrm{ec}}$ in summer than in spring. In autumn, NEE was significantly positively correlated with $T_{\text {soil }}$ from 0 to $50 \mathrm{~cm}$ and with $S W C$ from 0 to $10 \mathrm{~cm}$ but was significantly negatively correlated with SWC from 10 to $30 \mathrm{~cm}$. GPP and $R_{\text {ec }}$ were significantly positively correlated with $T_{\text {soil }}$ from 0 to $50 \mathrm{~cm}, \mathrm{SWC}$ from 10 to $50 \mathrm{~cm}$, and SWC from 0 to $10 \mathrm{~cm}$.

\section{Discussion}

\subsection{Annual and seasonal mean and diurnal variability}

\subsubsection{Comparison with other arid and semiarid ecosystems}

As we hypothesized, the sandy grassland ecosystem in the present study was a net $\mathrm{CO}_{2}$ source at an annual scale with an annual mean NEE of $49 \pm 8 \mathrm{~g} \mathrm{Cm}^{-2} \mathrm{yr}^{-1}$ in the years for which a complete dataset was available $(2015,2016$, and 2018). This result was consistent with results for other ecosystems with similar climate and geographical conditions. For example, a grassland in New Mexico, United States, was a net source of $31 \mathrm{~g} \mathrm{C} \mathrm{m}^{-2} \mathrm{yr}^{-1}$ during dry study periods (Petrie et al., 2015). A savanna in southern Arizona, United States, was also a net source of $\mathrm{CO}_{2}$ to the atmosphere, with emissions ranging from 14 to $95 \mathrm{~g} \mathrm{Cm}^{-2} \mathrm{yr}^{-1}$ and the strength of the source increasing with decreasing precipitation (Scott et al., 2014). A woodland in central Australia was carbon-neutral during a dry year (Cleverly et al., 2013). In contrast, many other arid and semiarid ecosystems 


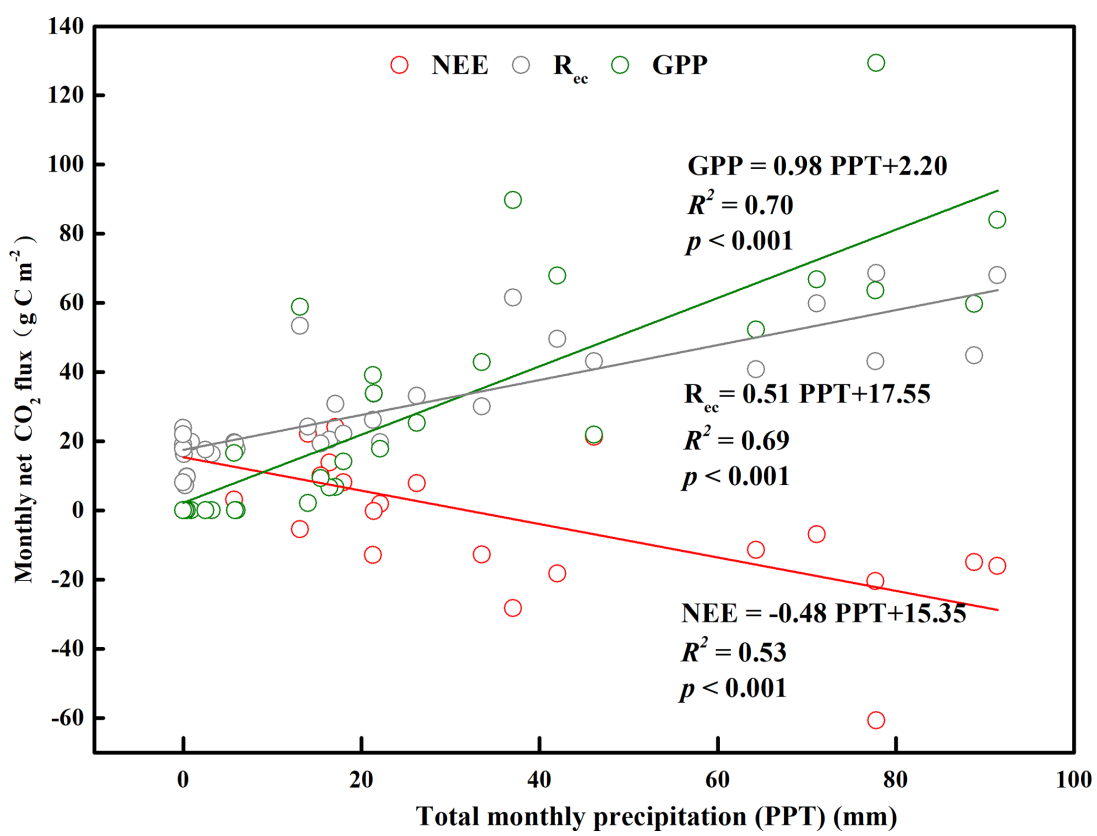

Figure 6. Relationship between total monthly precipitation (PPT) and monthly net ecosystem carbon exchange (NEE), gross primary productivity (GPP), and ecosystem respiration $\left(R_{\mathrm{ec}}\right)$ for the years with a complete dataset $(2015,2016$, and 2018$)$.
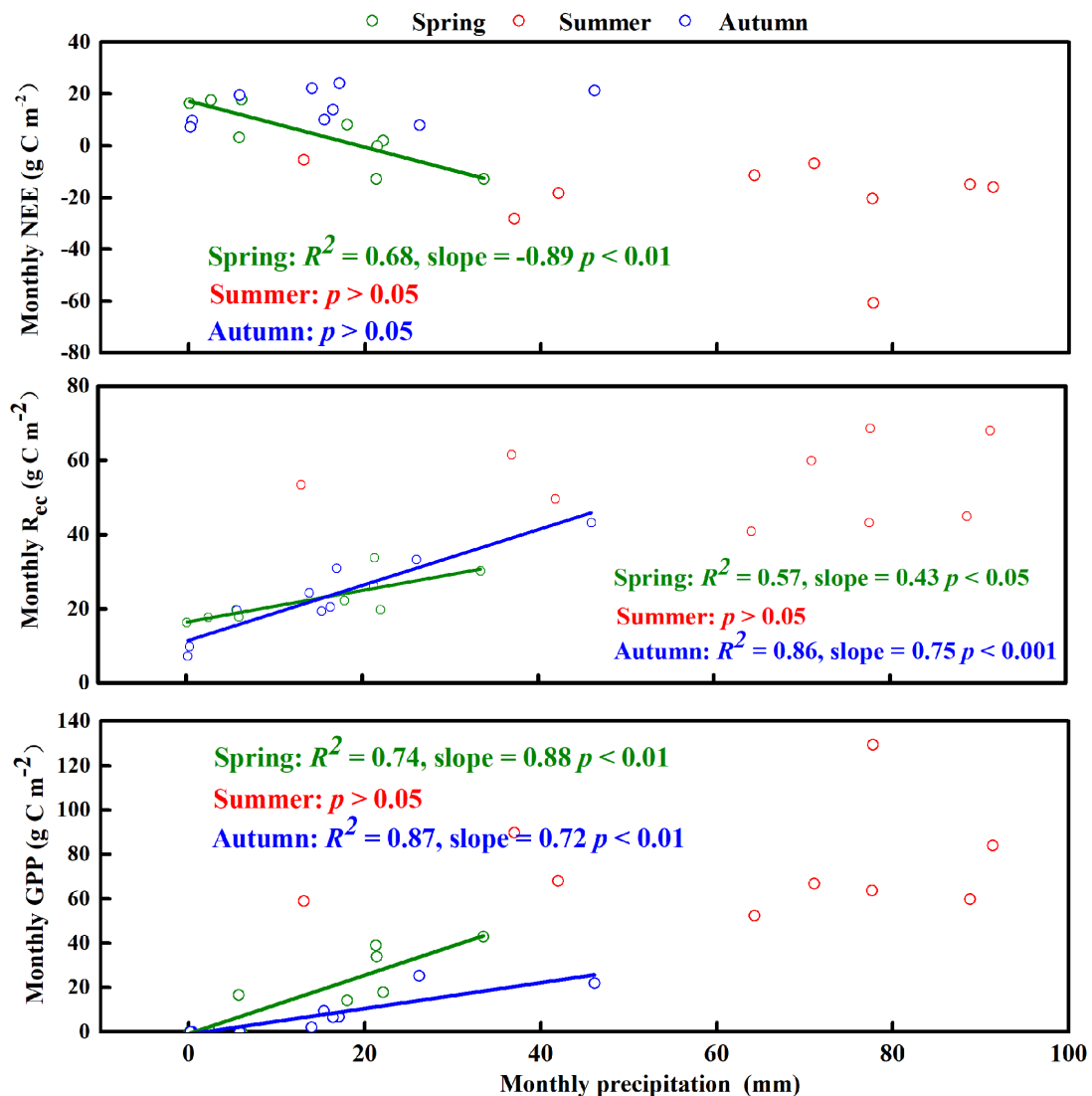

Figure 7. Relationship between monthly net ecosystem carbon exchange (NEE), gross primary productivity (GPP), and ecosystem respiration $\left(R_{\mathrm{ec}}\right)$ and the corresponding monthly precipitation in the spring (March-April-May), summer (June-July-August), and autumn (SeptemberOctober-November). 

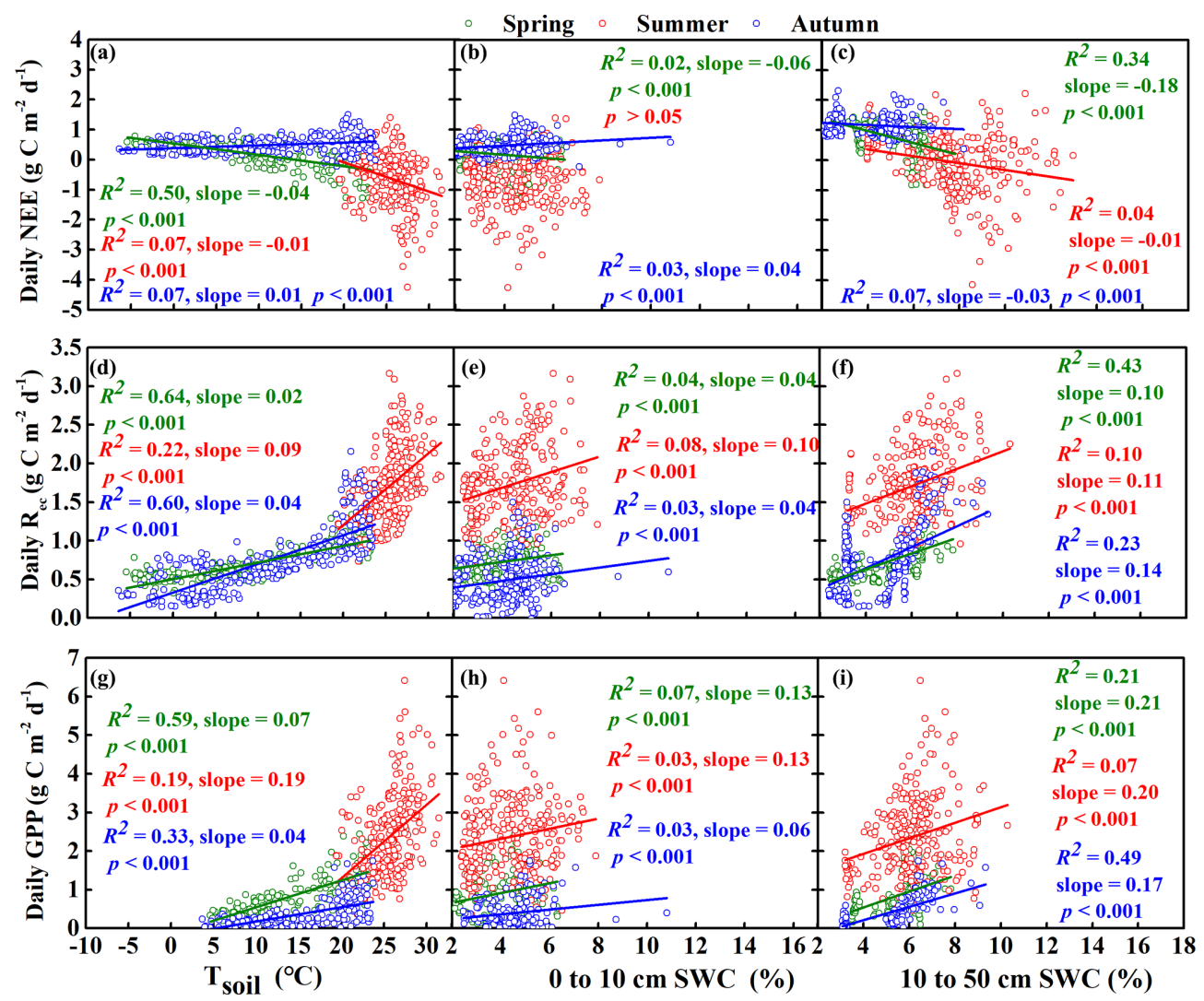

Figure 8. Relationships between daily net ecosystem carbon exchange (NEE), gross primary productivity (GPP), and ecosystem respiration $\left(R_{\mathrm{ec}}\right)$ and the average soil temperature to a depth of $50 \mathrm{~cm}\left(T_{\text {soil }}\right)$ and soil water content $(\mathrm{SWC})$. Before the regression analysis, $\mathrm{SWC}$ was divided into two depth ranges: the near-surface soil $(0$ to $10 \mathrm{~cm})$ and deeper soil $(10$ to $50 \mathrm{~cm})$. However, NEE was only correlated with SWC at depths of 40 and $50 \mathrm{~cm}$ in the summer and 20 and $30 \mathrm{~cm}$ in the autumn based on the results of a collinearity test for the three seasons. $T_{\text {soil }}$ was divided into a single range $(0$ to $50 \mathrm{~cm})$ based on the results of a collinearity test for the three seasons: spring (March-April-May), summer (June-July-August), and autumn (September-October-November).

were a significant net sink for $\mathrm{CO}_{2}$. For example, a desert ecosystem in the United States had net $\mathrm{C}$ sequestration of 102 to $110 \mathrm{~g} \mathrm{C} \mathrm{m}^{-2} \mathrm{yr}^{-1}$ (Wohlfahrt et al., 2008); an artificial sand-binding vegetation system in China's Tengger Desert had net sequestration of 14 and $23 \mathrm{~g} \mathrm{Cm}^{-2} \mathrm{yr}^{-1}$ in 2 consecutive years (Gao et al., 2012); a phreatophyte-dominated desert ecosystem in China's Gurbantünggüt Desert had net sequestration of 5 to $40 \mathrm{~g} \mathrm{Cm}^{-2} \mathrm{yr}^{-1}$ (Liu et al., 2016a); and a shrubland in China's Mu Us Desert had net sequestration of $77 \mathrm{~g} \mathrm{Cm}^{-2} \mathrm{yr}^{-1}$ (Jia et al., 2014).

The most likely reason for these differences among studies relates to the effects of vegetation cover variances and moisture. Our observations in 2015 and 2016 were in dry years with precipitation considerably below the long-term average, and because NEE was negatively related to precipitation (Fig. 6), this would have decreased carbon sequestration by the ecosystem. Previous studies showed that annual species such as the vegetation in our study area can be extremely vulnerable to drought (Jongen et al., 2011; Sun et al., 2015; Liu et al., 2016a). Drought was the main source of inter-annual variation in previous research on terrestrial carbon seques- tration as it decreases GPP and increases NEE (Webb et al., 1978; Sala et al., 1988; Ciais et al., 2005). It will be necessary to study NEE for a longer period to reveal when that change occurs and the ecosystem's long-term response to environmental and biological factors (Su et al., 2003; Niu et al., 2018).

\subsubsection{The seasonal and diurnal characteristics of carbon fluxes in the sandy grassland ecosystem}

In spring, the sandy grassland was a net $\mathrm{CO}_{2}$ source in all years (Fig. 4a). Before the summer growing season, both GPP and $R_{\mathrm{ec}}$ increased with increasing temperature and precipitation (Niu et al., 2011; Rey et al., 2011). However, plants are just beginning to germinate in the spring, so the carbon sequestration capacity of the ecosystem is less than the carbon release capacity (Delpierre et al., 2010; Liu et al., 2016a; Zhang et al., 2016). Therefore, the ecosystem was a net $\mathrm{CO}_{2}$ source.

In summer, the sandy grassland was a $\mathrm{CO}_{2}$ sink in all years (Fig. 4b). Our results agree with previous results for the study 
area (Li et al., 2015), as well as with results for a semiarid savanna in Australia (Hutley et al., 2005) and a grassland in California (Ma et al., 2007). GPP and $R_{\text {ec }}$ increased because of the favourable temperature and moisture conditions. Some studies showed that photosynthesis is greater than respiration during the peak of the growing season (Kemp, 1983; Liu et al., 2016a; Niu et al., 2018). Our result was consistent with these studies since Fig. 8 shows that these conditions increased carbon uptake (i.e., NEE became more negative). Then, because the sensitivity of GPP to $T_{\text {soil }}$ and moisture was greater than that of $R_{\mathrm{ec}}$, the ecosystem became a net $\mathrm{CO}_{2}$ sink.

In the autumn and winter, the sandy grassland was a net $\mathrm{CO}_{2}$ source in all years (Fig. $4 \mathrm{c}$ and d). At the end of the growing season (in autumn), annual plants begin to die and photosynthesis weakens (Fang et al., 2014). As a result, the ecosystem gradually transforms from a carbon sink to a carbon source (Keenan et al., 2009; Kiely et al., 2009). In winter, plants are either dead or dormant, so there is no $\mathrm{C}$ uptake.

At the diurnal scale, NEE in the spring and summer showed $\mathrm{CO}_{2}$ uptake during the day (06:00-18:00) and $\mathrm{CO}_{2}$ emission during the night (Fig. 5a and b), which agrees with previous research (Wagle and Kakani, 2014; Jia et al., 2014). In summer, the nighttime $R_{\mathrm{ec}}$ was higher than that in daytime (Fig. 5b). This may relate to two factors. On the one hand, soil respiration depends on photosynthesis because the litter and root exudates released by the plants are essential for microbial metabolism. However, the carbon sequestered by photosynthesis is transported to the roots after several hours and is released at night through rhizosphere respiration (Dilkes et al., 2004; Tang et al., 2005). On the other hand, the air temperature in daytime is higher than the soil temperature, and the gas pressure is also high, which can inhibit soil $\mathrm{CO}_{2}$ emission; because the soil temperature is higher than the air temperature at night, this is conducive to the diffusion and release of soil $\mathrm{CO}_{2}$ (Cao et al., 2005).

In autumn and winter, the sandy grassland ecosystem showed $\mathrm{CO}_{2}$ emission throughout the day (Fig. $5 \mathrm{c}$ and d). At a diurnal scale, there were two peaks for NEE (at sunrise and sunset) and a minimum during the day (Fig. 5d). This phenomenon may have resulted from heating effects in the open-path infrared gas analyzer since the surface of an open-path instrument can become substantially warmer than the ambient air due to heat generated by the electronics and by the radiation load during the day. In contrast, radiative cooling at night moderated the temperature increases in the optical path, especially under a clear sky. The instrument surfaces would warm the air to a temperature slightly higher than it was before it entered the optical path, and air expansion would take place. As a result, the $\mathrm{CO}_{2}$ number density would be lower than it would have been without the heating (Burba et al., 2008). Yearly estimates of NEE may be significantly biased toward $\mathrm{CO}_{2}$ uptake in cold-climate ecosystems and may need to be revised (Goulden et al., 2006; Grelle and Burba, 2007; Burba et al., 2008). We used the EddyPro software to calibrate the infrared gas analyzer by providing a self-heating correction during the winter. After correction, the NEE value changed from negative to positive (i.e., net emission), which realistically reflects the characteristics of NEE in winter. However, the correction does not completely eliminate the self-heating of the infrared gas analyzer (Burba et al., 2008), so the magnitude of the NEE value in the daytime in winter is smaller than that at night, which may also explain the two NEE peaks in the winter. We recently created a Li-Cor LI-8150 gas analyzer system with six long-term monitoring chambers and installed the system in the footprint area for the eddy covariance measurements, and we will use the data it generates in future research to test that hypothesis.

\subsection{Impacts of the environment on NEE, GPP, and $\boldsymbol{R}_{\mathrm{ec}}$}

\subsubsection{Effects of precipitation on carbon fluxes}

Understanding the relationships between precipitation patterns and inter-annual variations in carbon flux is an important step towards predicting how future climate change will affect carbon cycles in arid and semiarid ecosystems (Poulter et al., 2014; Scott et al., 2014; Liu et al., 2016a). Our results demonstrated the important roles of the environmental factors in regulating the direction and amount of NEE between the atmosphere and the ecosystem in a sandy grassland in the Horqin Sandy Land. The dominant environmental factors differed among seasons at different scales, as has been reported in previous research (Nakano et al., 2008; Ueyama et al., 2010).

At an annual scale, the amount of precipitation was the dominant factor in regulating the annual carbon exchange of this sandy grassland. NEE was negatively linearly related to precipitation on a monthly basis throughout the year (Fig. 6). This result is consistent with data from a northern temperate grassland in Canada (Flanagan et al., 2002) and a tallgrass prairie in the United States (Suyker et al., 2003). Annual herbaceous plants are vulnerable to decreased precipitation which decreases their productivity by reducing stomatal conductance and leaf area while simultaneously increasing the soil water deficit (Ford et al., 2008). Soil water deficits and decreased substrate availability for soil microbes can also decrease $R_{\text {ec }}$ (Shi et al., 2014). In addition, GPP generally responds more strongly than $R_{\mathrm{ec}}$ to drought in arid and semiarid areas (Schwalm et al., 2010; Litvak et al., 2015; Delgado-Balbuena et al., 2019). Our result was consistent with these studies as the slope of the regression line that relates precipitation to GPP $(0.98)$ was much higher than that for $R_{\text {ec }}(0.51)$ (Fig. 6). However, we must improve our understanding of the responses of the ecosystem to precipitation and the underlying mechanisms that control whether the ecosystem will be a carbon source or sink. To accomplish this, it will be necessary to observe the ecosystem continuously for a longer period of time. 


\subsubsection{Effects of environmental factors on seasonal carbon fluxes}

The dominant factors varied seasonally. In the spring, NEE was most strongly affected by $T_{\text {soil }}$ (Fig. 8), SWC (Fig. 8), pulses of effective precipitation (Fig. $2 b$ and $c$ ), and the amount of total monthly precipitation (Fig. 7). After experiencing the winter cold and drought, GPP and $R_{\mathrm{ec}}$ increased with increasing temperature and precipitation during the spring (Chu et al., 2013; Wolf et al., 2016). In the present study, NEE was negatively related to the amount of spring precipitation (Fig. 7), which suggests that spring precipitation leads to increased ecosystem carbon uptake in sandy grassland likely because the water replenishes the soil water storage in time to facilitate the emergence and growth of shallow-rooted annual plants (Scott et al., 2000; Liu et al., 2016a). In turn, this increases ecosystem $\mathrm{CO}_{2}$ uptake. Therefore, spring precipitation results in the greater emergence and growth of annuals, which leads to a higher contribution of this season to the ecosystem productivity (Huang et al., 2015).

In semiarid ecosystems such as our study site, summer precipitation supplies the majority of the annual precipitation and soil moisture for most of the annual plant growth (Emmerich and Verdugo, 2008; Sun et al., 2015). Our results showed that NEE was dominated by the total summer precipitation and by SWC at depths of 40 and $50 \mathrm{~cm}$. This is likely to be related to the total precipitation and the size of effective pulses. For example, the large precipitation pulses $(>20 \mathrm{~mm})$ significantly promoted carbon uptake by the ecosystem (Fig. 2b and c). Large precipitation pulses penetrate deeper into the soil, thereby recharging soil water in deeper layers, which stimulates plant growth and carbon absorption (Harper et al., 2005; Bell et al., 2012); on the other hand, the water can potentially move below the rooting zone and become unavailable to plants. However, our results indicated that the relationship between SWC from 0 to $10 \mathrm{~cm}$ and NEE was not significant in summer. The near-surface SWC would be closely linked to low precipitation amounts $(<5 \mathrm{~mm})$ that would not be effective (Fig. 2). Studies suggest that low precipitation amounts may be intercepted by the plant canopy or may replenish only the near-surface soil where water may evaporate before plants can take advantage of it, thereby reducing its impact on NEE (Schwinning and Sala, 2004; Hao et al., 2010). Therefore, the events with high precipitation appear to be more efficient than events with low precipitation for regulating NEE in sandy grassland in the summer.

In the autumn, NEE increased with increasing pulses of effective precipitation (Fig. 2c), with $T_{\text {soil }}$, and with SWC from 0 to $10 \mathrm{~cm}$ (Fig. 8). As was the case in the summer, the near-surface SWC was closely related to small precipitation events $(<5 \mathrm{~mm})$. However, unlike in the summer, autumn is cooler and moisture evaporates more slowly from the nearsurface soil, and microbial respiration is sensitive to precipi- tation when the temperature is suitable for microbial activity in semiarid regions (Huxman et al., 2004; Sponseller, 2006; Roby et al., 2019). Thus, small rainfall events can stimulate ecosystem $\mathrm{CO}_{2}$ loss chiefly through their effect on microbial respiration (Reynolds et al., 2004; Hao et al., 2010). However, the relationship between NEE and SWC in deeper soil layers was negative (Fig. 8c), which was similar to the relationship in summer,

In winter, the annual plants had withered, so there was no GPP and the entire ecosystem was characterized by carbon emission (Morgner et al., 2010; Gao et al., 2012). Our results showed that NEE increased with decreasing SWC below a depth of $20 \mathrm{~cm}$ and with decreasing temperature at all depths (Table S1). Previous studies found that when SWC decreases sufficiently to create water stress, it may replace temperature as the main factor that controls soil respiration in arid and semiarid areas in winter (Wu et al., 2010; Escolar et al., 2015), and as a result, soil respiration decreased with decreasing SWC (Manzoni et al., 2011; Oikawa et al., 2011). Our results were inconsistent with these previous studies. This may be due to the effects of drought since precipitation during the winter amounted to less than $1 \%$ of the annual precipitation, and this drought would be exacerbated by strong winter winds in the Horqin Sandy Land (Fig. S6 in the Supplement; Wang et al., 2005; Liu et al., 2016b). The soil organic matter and nutrients would also be lost faster when SWC decreases and the wind strengthens, resulting in increased carbon emission (Lal, 2004; Munodawafa, 2011).

\section{Conclusions}

Our field data indicated that the sandy grassland has functioned as a net $\mathrm{CO}_{2}$ source at an annual scale with a mean annual NEE of $49 \pm 8 \mathrm{~g} \mathrm{Cm}^{-2} \mathrm{yr}^{-1}$. At the seasonal scale, the sandy grassland showed net $\mathrm{CO}_{2}$ absorption during the summer but net $\mathrm{CO}_{2}$ release in the other seasons. At the diurnal scale, the ecosystem showed a strong single daytime absorption peak in the spring and summer but strong $\mathrm{CO}_{2}$ emission at night. In autumn and winter, the ecosystem was characterized by $\mathrm{CO}_{2}$ emission throughout the day.

The amount of precipitation was significantly negatively correlated with NEE on an annual basis; that is, more $\mathrm{CO}_{2}$ was sequestered at higher precipitation levels. Seasonally, NEE was mainly affected by $T_{\text {soil }}$, the pulses of effective precipitation, and the total amount of monthly precipitation in the spring, by the amount of total seasonal precipitation and large-pulse precipitation in summer, by $T_{\text {soil }}$ and SWC at all depths in autumn, and by $T_{\text {soil }}$ at all depths and by SWC from 30 to $50 \mathrm{~cm}$ in winter. Our findings demonstrated the importance of long-term, high-frequency field monitoring in sandy land to improve our understanding of $\mathrm{CO}_{2}$ cycling and its likely responses to a changing climate. However, it will be necessary to study the ecosystem's NEE for a longer period to reveal its long-term response to environmental and 
biological factors and learn when the ecosystem will recover sufficiently to become a net carbon sink on an annual basis.

Data availability. In agreement with the FAIR data standards, the data used in this article are archived, published, and available in a dedicated repository: https://doi.org/10.4121/uuid:35deeb02-816549b7-af8d-160d537ae15a.

Supplement. The supplement related to this article is available online at: https://doi.org/10.5194/bg-17-6309-2020-supplement.

Author contributions. YL, YN, HY, XW, and YD designed the study; YN, XG, and JL performed the experiments. YN and HY analyzed the data. YN drafted the paper. All co-authors had a chance to review the paper before submission and contributed to the discussion and interpretation of the data.

Competing interests. The authors declare that they have no conflict of interest.

Acknowledgements. We thank three anonymous referees for their excellent and insightful reviews. We further thank Geoffrey Hart for his improvements on the English language and style of the paper.

Financial support. This research has been supported by the National Key Research and Development Program of China (grant nos. 2017YFA0604803 and 2016YFC0500901), the National Natural Science Foundation of China (grant nos. 31971466, 31560161, 31260089, and 31400392), the Chinese Academy of Sciences "Light of West China" Program (grant no. 18JR3RA004), and the One Hundred Person Project of the Chinese Academy of Sciences (grant no. Y551821).

Review statement. This paper was edited by Trevor Keenan and reviewed by three anonymous referees.

\section{References}

Ago, E. E., Agbossou, E. K., Cohard, J. M., Galle, S., and Aubinet, M.: Response of $\mathrm{CO}_{2}$ fluxes and productivity to water availability in two contrasting ecosystems in northern Benin (West Africa), Ann. For. Sci., 73, 483-500, https://doi.org/10.1007/s13595-016-0542-9, 2016.

Asner, G. P., Archer, S., Hughes, R. F., Ansley, R. J., and Wessman, C. A.: Net changes in regional woody vegetation cover and carbon storage in Texas Drylands, 1937-1999, Glob. Change Biol., 9, 316-335, https://doi.org/10.1046/j.1365-2486.2003.00594.x, 2003.

Bagan, H., Takeuchi, W., Kinoshita, T., and Bao, Y. H.: Land cover classification and change analysis in the Horqin Sandy
Land from 1975 to 2007, IEEE J. Sel. Top. Appl., 3, 168-177, https://doi.org/10.1109/jstars.2010.2046627, 2010.

Baldocchi, D., Falage, E., Gu, L, H., Olson, R., Hollinger, D., Running, S., Anthoni, P., Bernhofer, C., Davis, K., Evans, R., Fuentes, J., Goldstein, A., Katul, G., Law, B., Lee, X. H., Malhi, Y., Meyers, T., Munger, W., Oechel, W., Paw, U. K. T., Pilegaard, K., Schmid, H. P., Valentini, R., Verma, S., Vesala, T., Wilson, K., and Wofsy, S.: Fluxnet: a new tool to study the temporal and spatial variability of ecosystem-scale carbon dioxide, water vapor, and energy flux densities, B. Am. Meteorol. Soc., 82, 2415-2434, https://doi.org/10.1175/15200477(2001)082<2415:FANTTS>2.3.CO;2, 2001.

Barrett, G. W.: The effects of an acute insecticide stress on a semi-enclosed grassland ecosystem, Ecology, 49, 1019, https://doi.org/10.2307/1934487, 1968.

Bell, T. W., Menzer, O., Troyo-Diequez, E., and Oechel, W. C.: Carbon dioxide exchange over multiple temporal scales in an arid shrub ecosystem near La Paz, Baja California Sur, Mexico, Glob. Change Biol., 18, 2570-2582, https://doi.org/10.1111/j.13652486.2012.02720.x, 2012.

Biederman, J. A., Scott, R. L., Goulden, M. L., Vargas, R., Litvak, M. E., Kolb, T. E., Yepez, E. A., Oechel, W. C., Blanken, P. D., Bell, T. W., Garatuza-Payan, J., Maurer, G. E., Dore, S., and Burns, S. P.: Terrestrial carbon balance in a drier world: the effects of water availability in southwestern North America, Glob. Change Biol., 22, 1867-1879, https://doi.org/10.1111/gcb.13222, 2016.

Biederman, J. A., Scott, R. L., Bell, T. W., Bowling. D. R., Dore, S., Garatuza-Payan, J., Kolb, T. E., Krishnan, P., Krofchec, D. J., Litv, M. E., Maurer, G. E., Meyers, T. P., Oechel, W. C., Papuga, S. A., Ponce-Campos, G. E., Rodriguez, J. C., Smith, W. K., Vargas, R., Watts, C. J., Yepez, E. A., and Goulden, M. L.: $\mathrm{CO}_{2}$ exchange and evapotranspiration across dryland ecosystems of southwestern North America, Glob. Change Biol., 23, 4204-4221, https://doi.org/10.1111/gcb.13686, 2017.

Burba, G. G., McDermitt, D. K., Grelle, A., and Daniel, J. A.: Addressing the influence of instrument surface heat exchange on the measurements of $\mathrm{CO}_{2}$ flux from open-path gas analyzers, Glob. Change Biol., 14, 1854-1876, https://doi.org/10.1111/j.13652486.2008.01606.x, 2008.

Cao, J. H., Song, L. H., Jiang, G. H., Xie, Y. Q., You, S. Y.: Diurnal dynamics of soil respiration and carbon stable isotope in $\mathrm{Lu}-$ nan stone forest, Yunnan Province, Carsologica Sinica, 24, 2327, https://doi.org/10.3969/j.issn.1001-4810.2005.01.003, 2005 (in Chinese).

Chen, S. P., Lin, G. H., Huang, J. H., and Jenerette, G. D.: Dependence of carbon sequestration on the differential responses of ecosystem photosynthesis and respiration to rain pulses in a semiarid steppe, Glob. Change Biol., 15, 2450-2461, https://doi.org/10.1111/j.1365-2486.2009.01879.x, 2009.

Chu, J. M., Wang, Q., Fan, Z. P., and Li, F. Y.: Effects of soil moisture condition and freeze-thaw cycle on soil respiration of different land-use types in Horqin Sandy Land, Chinese J. Ecol., 32, 1399-1404, available at: http://www.cje.net.cn/EN/Y2013/V32/ I6/1399 (last access: 8 December 2020), 2013 (in Chinese).

Ciais, P. H., Reichstein, M., Viovy, N., Granier, A., Ogée, J., Allard, V., Aubinet, M., Buchmann, N., Bernhofer, C., Carrara, A., Chevallier, F., Noblet, N. D., Friend, A. D., Friedlingstein, P., Grünwald, T., Heinesch, B., Keronen, P., Knohl, A., Krin- 
ner, G., Loustau, D., Manca, G., Matteucci, G., Miglietta, F., Ourcival, J. M., Papale, D., Pilegaard, K., Rambal, S., Seufert, G., Soussana, J. F., Sanz, M. J., Schulze, E. D., Vesala, T., and Valentini, R.: Europe-wide reduction in primary productivity caused by the heat and drought in 2003, Nature, 437, 529-533, https://doi.org/10.1038/nature03972, 2005.

Cleverly, J., Boulain, N., Villalobos-Vega, R., Grant, N., Faux, R., Wood, C., Cook, P. G., Yu, Q., Leigh, A., and Eamus, D.: Dynamics of component carbon fluxes in a semi-arid Acacia woodland, central Australia, J. Geophys. Res.-Biogeo., 118, 11681185, https://doi.org/10.1002/jgrg.20101, 2013.

Cleverly, J., Eamus, D., Gorsel, E. V., Chen, C., Rumman, R., Luo, Q. Y., Coupe, N. R., Li, L. H., Kljun, N., Faux, R., Yu, Q., and Huete, A.: Productivity and evapotranspiration of two contrasting semiarid ecosystems following the 2011 global carbon land sink anomaly, Agr. Forest Meteorol., 220, 151-159, https://doi.org/10.1016/j.agrformet.2016.01.086, 2016.

Czobel, S., Szirmai, O., Nemeth, Z., Gyuricza, C., Házi, J., Tóth, A., Schellenberger, J., Vasa, L., and Penksza, K.: Short-term effects of grazing exclusion on net ecosystem $\mathrm{CO}_{2}$ exchange and net primary production in a Pannonian sandy grassland, Notulae Botanicae Horti Agrobotanici Cluj-Napoca, 40, 67-72, https://doi.org/10.15835/nbha4028300, 2012.

Delgado-Balbuena, J., Arredondo, J. T., Loescher, H. W., PinedaMartínez, L. F., Carbajal, J. N., and Vargas, R.: Seasonal precipitation legacy effects determine the carbon balance of a semiarid grassland, J. Geophys. Res.-Biogeo., 124, 987-1000, https://doi.org/10.1029/2018JG004799, 2019.

Delpierre, N., Soudani, K., Francois, C., Pontailler, J. Y., Nikinmaa, E., Misson, L., Aubinet, M., Bernhofer, C., Granier, A., Grünwald, T., Heinesch, B., Longdoz, B., Ourcival, J. M., Rambal, S., Vesala, T., and Dufrene, E.: Exceptional carbon uptake in European forests during the 2007 warm spring: a data-model analysis, Glob. Change Biol., 15, 1455-1474, https://doi.org/10.1111/j.1365-2486.2008.01835.x, 2010.

Dilkes, N. B., Jones, D. L., Farrar, J.: Temporal dynamics of carbon partitioning and rhizodeposition in wheat. Plant Physiol., 134, 706-715, https://doi.org/10.1104/pp.103.032045, 2004.

Emmerich, W. E.: Carbon dioxide fluxes in a semiarid environment with high carbonate soils, Agr. Forest Meteorol., 116, 91-102, https://doi.org/10.1016/s0168-1923(02)00231-9, 2003.

Emmerich, W. E. and Verdugo, C. L.: Precipitation thresholds for $\mathrm{CO}_{2}$ uptake in grass and shrub plant communities on Walnut Gulch Experimental Watershed, Water Resour. Res., 44, 435443, https://doi.org/10.1029/2006wr005690, 2008.

Escolar, C., Maestre, F. T , and Rey. A.: Biocrusts modulate warming and rainfall exclusion effects on soil respiration in a semi-arid grassland, Soil Biol. Biochem., 80, 9-17, https://doi.org/10.1016/j.soilbio.2014.09.019, 2015.

Falge, E., Baldocchi, D., Olson, R., Anthoni, P., and Dolman, H.: Gap filling strategies for defensible annual sums of net ecosystem exchange, Agr. Forest Meteorol., 107, 43-69, https://doi.org/10.1016/S0168-1923(00)00225-2, 2001.

Fang, S. X., Zhou, L. X., Tans, P. P., Ciais, P., Steinbacher, M., Xu, L., and Luan, T.: In situ measurement of atmospheric $\mathrm{CO}_{2}$ at the four WMO/GAW stations in China, Atmos. Chem. Phys., 14, 2541-2554, https://doi.org/10.5194/acp-14-2541-2014, 2014.

Flanagan, L. B., Wever, L. A., and Carlson, P. J.: Seasonal and interannual variation in carbon dioxide exchange and carbon balance in a northern temperate grassland, Glob. Change Biol., 8, 599615, https://doi.org/10.1046/j.1365-2486.2002.00491.x, 2002.

Ford, C. R., Mitchell, R. J., and Teskey, R. O.: Water table depth affects productivity, water use, and the response to nitrogen addition in a savanna system, Can. J. Forest Res., 38, 2118-2127, https://doi.org/10.1139/X08-061, 2008.

Gao, Y. H., Li, X. R., Liu, L. C., Jia, R. L., Yang, H. T., Li, G., and Wei, Y. P.: Seasonal variation of carbon exchange from a revegetation area in a Chinese desert, Agr. Forest Meteorol., 156, 134142, https://doi.org/10.1016/j.agrformet.2012.01.007, 2012.

Goulden, M. L., Winston, G. C., McMillan, A. M. S., Litvak, M. E., Read, E. L., Rocha, A. V., and Elliot, J. R.: An eddy covariance mesonet to measure the effect of forest age on land-atmosphere exchange, Glob. Change Biol., 12, 2146-2162, https://doi.org/10.1111/j.1365-2486.2006.01251.x, 2006.

Grelle, A. and Burba, G. G.: Fine-wire thermometer to correct $\mathrm{CO}_{2}$ fluxes by open-path analyzers for artificial density fluctuations. Agr. Forest Meteorol., 147, 48-57, https://doi.org/10.1016/j.agrformet.2007.06.007, 2007.

Hair, J. F., Black, B., Babin, B., Anderson, R. E., and Tatham, R. L.: Multivariate data analysis, 6th edn., Prentice Hall, New Jersey, 2005.

Hao, Y. B., Wang, Y. F., Mei, X., and Cui, X. R.: The response of ecosystem $\mathrm{CO}_{2}$ exchange to small precipitation pulses over a temperate steppe, Plant Ecol., 209, 335-347, https://doi.org/10.1007/s11258-010-9766-1, 2010.

Harper, C. W., Blair, J. M., Fay, P. A., Knapp, A. K., and Carlisle, J. D.: Increased rainfall variability and reduced rainfall amount decreases soil $\mathrm{CO}_{2}$ flux in a grassland ecosystem, Glob. Change Biol., 11, 322-334, https://doi.org/10.1111/j.13652486.2005.00899.x, 2005.

Hastings, S. J., Oechel, W. C., and Muhliamelo, A.: Diurnal, seasonal and annual variation in the net ecosystem $\mathrm{CO}_{2}$ exchange of a desert shrub community (sarcocaulescent) in Baja California, Mexico, Glob. Change Biol., 11, 927-939, https://doi.org/10.1111/j.1365-2486.2005.00951.x, 2010.

Huang, G., Li, Y., and Collins, B.: Phenological transition dictates the seasonal dynamics of ecosystem carbon exchange in a desert steppe, J. Veg. Sci., 26, 337-347, https://doi.org/10.1111/jvs.12236, 2015.

Hutley, L. B., Leuning, R., Beringer, J., and Cleugh, H. A.: The utility of the eddy covariance techniques as a tool in carbon accounting: tropical savanna as a case study, Aust. J. Bot., 53, 663, https://doi.org/10.1071/Bt04147, 2005.

Huxman, T. E., Snyder, K. A., Tissue, D., Leffler, A. J., Ogle, K., Pockman, W. T., Sandquist, D. R., Potts, D. L., and Schwinning, S.: Precipitation pulses and carbon fluxes in semiarid and arid ecosystems, Oecologia, 141, 254-268, https://doi.org/10.1007/s00442-004-1682-4, 2004.

Jia, X., Zha, T. S., Wu, B., Zhang, Y. Q., Gong, J. N., Qin, S. G., Chen, G. P., Qian, D., Kellomäki, S., and Peltola, H.: Biophysical controls on net ecosystem $\mathrm{CO}_{2}$ exchange over a semiarid shrubland in northwest China, Biogeosciences, 11, 4679-4693, https://doi.org/10.5194/bg-11-4679-2014, 2014

Jongen, M., Pereira, J. S., Aires, L. M. I., and Pio, C. A.: The effects of drought and timing of precipitation on the inter-annual variation in ecosystem-atmosphere exchange in a mediterranean grassland. Agr. Forest Meteorol., 151, 595-606, https://doi.org/10.1016/j.agrformet.2011.01.008, 2011. 
Joseph Turk, F., Pasadena, J. P. L., Li, L., and Haddad, Z. S.: Physical modeling of microwave surface emissivity from passive microwave satellite observations room 256 (New Orleans Convention Center), AMS (American Meteorological Society) 18th Conference Satellite Meteorology and Oceanography, New Orleans, 23 January 2012.

Kang, W. P., Wang. T., and Liu, S. L.: The response of vegetation phenology and productivity to drought in semi-arid regions of Northern China, Remote Sens.-Basel, 10, 727, https://doi.org/10.3390/rs10050727, 2018.

Keenan, T., García, R., Friend, A. D., Zaehle, S., Gracia, C., and Sabate, S.: Improved understanding of drought controls on seasonal variation in Mediterranean forest canopy $\mathrm{CO}_{2}$ and water fluxes through combined in situ measurements and ecosystem modelling, Biogeosciences, 6, 1423-1444, https://doi.org/10.5194/bg-6-1423-2009, 2009.

Kemp, P. R.: Phenological patterns of Chihuahuan desert plants in relation to the timing of water availability, J. Ecol., 71, 427-436, https://doi.org/10.2307/2259725, 1983.

Kiely, G., Leahy, P., Sottocornola, M., Laine, A., Mishurov, M., Albertson, J., and Carton, O.: Celticflux: measurement and modelling of greenhouse gas fluxes from grasslands and a peatland in Ireland. Irish Environmental Protection Agency, STRIVE Report 24, available at: http://www.epa.ie/pubs/reports/research/ climate/strivereport24.html (last access: 8 December 2020), 2009.

Knorr, W., Prentice, I. C., House, J. I., and Holland, E. A.: Longterm sensitivity of soil carbon turnover to warming, Nature, 433, 298-301, https://doi.org/10.1038/nature03226, 2005.

Lal, R.: Carbon sequestration in dryland ecosystems, Environ. Manage., 33, 528-544, https://doi.org/10.1007/s00267-003-9110-9, 2004.

Lee, X. H., Massman, W. J., and Law, B. E.: Handbook of micrometeorology, Vol. 29 of the Atmospheric and Oceanographic Sciences Library, https://doi.org/10.1007/1-4020-2265-4, Springer, Berlin, 2004.

Li, L., Wang, Y. P., Beringer, J., Shi, H., Cleverly, J., Cheng, L., Eamus, D., Huete, A., Hutley, L., Lu, X. J., Piao, S. L., and Zhang, L.: Responses of LAI to rainfall explain contrasting sensitivities to carbon uptake between forest and non-forest ecosystems in Australia, Sci. Rep.-UK, 7, 11720, https://doi.org/10.1038/s41598-017-11063-w, 2017.

Li, R. P. and Zhou, G. S.: A temperature-precipitation based leafing model and its application in Northeast China, Plos One, 7, e33192, https://doi.org/10.1371/journal.pone.0033192, 2012.

Li, Y. Q., Zhao, X. Y., Chen, Y. P., Luo, Y. Q., and Wang, S. K.: Effects of grazing exclusion on carbon sequestration and the associated vegetation and soil characteristics at a semi-arid desertified sandy site in Inner Mongolia, northern China, Can. J. Soil Sci., 92, 807-819, https://doi.org/10.4141/cjss2012-030, 2012.

Li, Y. Q., Zhao, X. Y., Wang, S. K., Zhang, F. X., Lian, J., Huang, W. D., and Qu, H.: Carbon accumulation in the bulk soil and different soil fractions during the rehabilitation of desertified grassland in Horqin Sandy Land (northern China), Pol. J. Ecol., 63, 88101, https://doi.org/10.3161/15052249PJE2015.63.1.008, 2015.

Li, Y. Q., Zhang, J. P., Zhao, X. Y., Zhang, T. H., Li, Y. L., Liu, X. P., and Chen, Y. P.: Comparison of soil physico-chemical properties under different land-use and cover types in northeastern China's
Horqin Sandy Land, Sciences in Cold and Arid Regions, 8, 495506, https://doi.org/10.3724/SP.J.1226.2016.00495, 2016.

Li, Y. Q., Wang X. Y., Chen, Y. P., Luo, Y. Q., Lian, J., Niu, Y. Y., Gong, X. W., Yang, H., and Yu, P. D.: Changes in surface soil organic carbon in semiarid degraded Horqin Grassland of northeastern China between the 1980s and the 2010s, Catena, 174, 217-226, https://doi.org/10.1016/j.catena.2018.11.021, 2019.

Litvak, M. E., Krofcheck, D. J., and Maurer, G.: Quantifying the resilience of carbon dynamics in semi-arid biomes in the Southwestern U.S. to drought, in: Am. Geophys. Union Fall. Meeting, Abstract, San Francisco, 14 December 2015, B11N-01, 2015.

Liu, R., Cieraad, E., Li, Y., and Ma, J. J. E.: Precipitation pattern determines the inter-annual variation of herbaceous layer and carbon fluxes in a phreatophyte-dominated desert ecosystem, Ecosystems, 19, 601-614, https://doi.org/10.1007/s10021015-9954-x, 2016a.

Liu, S. L., Kang, W. P., and Wang, T.: Drought variability in Inner Mongolia of northern China during 1960-2013 based on standardized precipitation evapotranspiration index, Environ. Earth Sci., 75, 145, https://doi.org/10.1007/s12665-015-4996-0, $2016 b$.

Lloyd, J. and Taylor, J. A.: On the temperature dependence of soil respiration, Funct. Ecol., 8, 315-323, https://doi.org/10.2307/2389824, 1994.

Ma, S. Y., Baldocchi, D. D., Xu, L. K., and Hehn, T.: Interannual variability in carbon dioxide exchange of an oak/grass savanna and open grassland in California. Agr. Forest Meteorol., 147, 157-171, https://doi.org/10.1016/j.agrformet.2007.07.008, 2007.

Manzoni, S., Schimel, J. P., and Porporato, A.: Physical vs. physiological controls on water-stress in soil microbial communities, in: 96th ESA Annual Convention 2011, Austin Convention Center, 11 August 2011, https://doi.org/10.1890/11-0026.1, 2011.

Morgner, E., Elberling, B., Strebel, D., and Cooper, E. J.: The importance of winter in annual ecosystem respiration in the high arctic: effects of snow depth in two vegetation types, Polar Res., 29, 58-74, https://doi.org/10.1111/j.1751-8369.2010.00151.x, 2010.

Munkhdalai, Z. A., Feng, Z. W., Wang, X. K., and Sun, H. W.: Sandy grassland blowouts in Hulunbuir, northeast China: geomorphology, distribution, and causes, Prog. Nat. Sci.-Mater., 17, 68-73, https://doi.org/10.1080/10020070612331343227, 2007.

Munodawafa, A.: Maize grain yield as affected by the severity of soil erosion under semi-arid conditions and granitic sandy soils of Zimbabwe, Phys. Chem. Earth Pt. A/B/C, 36, 963-967, https://doi.org/10.1016/j.pce.2011.07.068, 2011.

Nakano, T., Nemoto, M., and Shinoda, M.: Environmental controls on photosynthetic production and ecosystem respiration in semiarid grasslands of Mongolia, Agr. Forest Meteorol., 148, 14561466, https://doi.org/10.1016/j.agrformet.2008.04.011, 2008.

Niu, S, L., Wu, M, Y., Han, Y., Xia, J, Y., Li, L, H., and Wan, S, Q.: Water-mediated responses of ecosystem carbon fluxes to climatic change in a temperate steppe, New Phytol., 177, 209-219, https://doi.org/10.1111/j.1469-8137.2007.02237.x, 2008.

Niu, S, L., Luo, Y, Q., Fei, S, F., and Montagnani, L.: Seasonal hysteresis of net ecosystem exchange in response to temperature change: patterns and causes, Glob. Change Biol., 17, 3102-3114, https://doi.org/10.1111/j.1365-2486.2011.02459.x, 2011. 
Niu, Y. Y., Li, Y. Q., Wang, X. Y., Gong, X. W., Luo, Y. Q., and Tian, D.Y.: Characteristics of annual variation in net carbon dioxide flux in a sandy grassland ecosystem during dry years, Acta Prataculturae Sinica, 27, 215-221, https://doi.org/10.11686/cyxb2017231, 2018 (in Chinese).

Nosetto, M. D., Jobbágy, E. G., and Paruelo, J. M.: Carbon sequestration in semi-arid rangelands: comparison of Pinus ponderosa plantations and grazing exclusion in NW Patagonia, J. Arid Environ., 67, 142-156, https://doi.org/10.1016/j.jaridenv.2005.12.008, 2006.

Noy-Meir, I.: Desert ecosystems: environment and producers, Annu. Rev. Ecol. Syst., 4, 25-51, https://doi.org/10.1146/annurev.es.04.110173.000325, 1973.

Oikawa, P., Grantz, D. A., and Jenerette, D.: Variation in the temperature sensitivity of heterotrophic soil respiration in response to pulse water events and substrate limitation, in: Am. Geophys. Union Fall Meeting, Abstract, San Francisco, 5-9 December 2011, B21F-0326, 2011.

Petrie, M. D., Collins, S. L., Swann, A. M., Ford, P. L., and Litvak, M. E.: Grassland to shrubland state transitions enhance carbon sequestration in the northern Chihuahuan desert, Glob. Change Biol., 21, 1226-1235, https://doi.org/10.1111/gcb.12743, 2015.

Ponce Campos, G. E., Moran, M. S., Huete, A., Zhang, Y., Bresloff, C., Huxman, T. E., Eamus, D., Bosch, D. D., Buda, A. R., Gunter, S. A., Scalley, T. H., Kitchen, S. G., McClaran, M. P., McNab, W. H., Montoya, D. S., Morgan, J. A., Peters, D. P. C., Sadler, E. J., Seyfried, M. S., and Starks, P. J.: Ecosystem resilience despite large-scale altered hydroclimate conditions, Nature, 494, 349352, https://doi.org/10.1038/nature11836, 2013.

Poulter, B., Frank, D., Ciais, P., Myneni, R. B., Andela, N., Bi, J., Broquet, G., Canadell, J. G., Chevallier, F., and Liu, Y. Y.: Contribution of semi-arid ecosystems to interannual variability of the global carbon cycle, Nature, 509, 600-603, https://doi.org/10.1038/nature13376, 2014.

Prevéy, J. S., Seastedt, T. R., and Wilson, S.: Seasonality of precipitation interacts with exotic species to alter composition and phenology of a semi-arid grassland, J. Ecol., 102, 1549-1561, https://doi.org/10.1111/1365-2745.12320, 2014.

Reichstein, M., Falge, E., Baldocchi, D., Papale, D., Aubinet, M., Berbigier, P., Bernhofer, C., Buchmann, N., Gilmanov, T., and Granier, A.: On the separation of net ecosystem exchange into assimilation and ecosystem respiration: review and improved algorithm, Glob. Change Biol., 11, 1424-1439, https://doi.org/10.1111/j.1365-2486.2005.001002.x, 2005.

Rey, A., Pegoraro, E., Oyonarte, C., Were, A., Escribano, P., and Raimundo, J.: Impact of land degradation on soil respiration in a steppe (Stipa tenacissima L.) semi-arid ecosystem in the SE of Spain, Soil Biol. Biochem., 43, 393-403, https://doi.org/10.1016/j.soilbio.2010.11.007, 2011.

Reynolds, J. F., Kemp, P. R., Ogle, K., and Fernandez, R. J.: Modifying the "pulse-reserve" paradigm for deserts of North America: precipitation pulses, soil water and plant responses, Oecologia, 141, 194-210, https://doi.org/10.1007/s00442-004-1524-4, 2004.

Roby, M. C., Scott, R. L., Barron-Gafford, G. A., Hamerlynck, E. P., and Moore, D. J. P.: Environmental and vegetative controls on soil $\mathrm{CO}_{2}$ efflux in three semiarid ecosystems, Soil Systems, 3, 1-19, https://doi.org/10.3390/soilsystems3010006, 2019.
Ruiz-Jaen, M. C. and Aide, T. M.: Restoration success: how is it being measured?, Restor. Ecol., 13, 569-577, https://doi.org/10.1111/j.1526-100X.2005.00072.x, 2005.

Sala, O. E., Parton, W. J., Joyce, L. A., and Lauenroth, W. K.: Primary production of the central grassland region of the United States, Ecology, 69, 40-45, https://doi.org/10.2307/1943158, 1988.

Schmid, H. P.: Experimental design for flux measurements: matching scales of observations and fluxes. Agr. Forest Meteorol., 87, 179-200, https://doi.org/10.1016/S0168-1923(97)00011-7, 1997.

Schwalm, C. R., Williams, C. A., Schaefer, K., Arneth, A., Bonal, D., Buchmann, N., Chen, J., Law, B. E., Lindroth, A., Luyssaert, S., Reichstein, M., and Richardson, A. D.: Assimilation exceeds respiration sensitivity to drought: a FLUXNET synthesis, Glob. Change Biol., 16, 657-670, https://doi.org/10.1111/j.13652486.2009.01991.x, 2010.

Schwinning, S. and Sala, O. E.: Hierarchy of responses to resource pulses in arid and semi-arid ecosystems, Oecologia, 141, 211220, https://doi.org/10.1007/s00442-004-1520-8, 2004.

Scott, R. L., Shuttleworth, W. J., Goodrich, D. C., and Maddock, T.: The water use of two dominant vegetation communities in a semiarid riparian ecosystem, Agr. Forest Meteorol., 105, 241256, https://doi.org/10.1016/s0168-1923(00)00181-7, 2000.

Scott, R. L., Jenerette, G. D., Potts, D. L., and Huxman, T. E.: Effects of seasonal drought on net carbon dioxide exchange from a woody-plant-encroached semiarid grassland, J. Geophys. Res.Biogeo., 114, G04004, https://doi.org/10.1029/2008jg000900, 2009.

Scott R. L., Huxman, T. E., Barron-Gafford, G. A., Jenerette, G. D., Young, J. M., and Hamerlynck, E. P.: When vegetation change alters ecosystem water availability, Glob. Change Biol., 20, 2198 2210, https://doi.org/10.1111/gcb.12511, 2014.

Scott, R. L., Biederman, J. A., Hamerlynck, E. P., and BarronGafford, G. A.: The carbon balance pivot point of southwestern U.S. semiarid ecosystems: insights from the $21 \mathrm{st}$ century drought, J. Geophys. Res.-Biogeo., 120, 2612-2624, https://doi.org/10.1002/2015JG003181, 2015.

Shen, M. G., Piao, S. L., Cong, N., Zhang, G.X., and Jassens, I. A.: Precipitation impacts on vegetation spring phenology on the Tibetan Plateau, Glob. Change Biol., 21, 3647-3656, https://doi.org/10.1111/gcb.12961, 2015.

Shi, Z., Thomey, M. L., Mowll, W., Litvak, M., Brunsell, N. A., Collins, S. L., Pockman, W. T., Smith, M. D., Knapp, A. K., and Luo, Y.: Differential effects of extreme drought on production and respiration: synthesis and modeling analysis, Biogeosciences, 11, 621-633, https://doi.org/10.5194/bg-11-621-2014, 2014.

Sponseller, R. A.: Precipitation pulses and soil $\mathrm{CO}_{2}$ flux in a Sonoran Desert ecosystem, Glob. Change Biol., 13, 426-436, https://doi.org/10.1111/j.1365-2486.2006.01307.x, 2006.

Su, Y. Z., Zhao, H. L., and Zhang, T. H.: Influence of grazing and enclosure on carbon sequestration in degraded sandy grassland, Inner Mongolia, North China, J. Environ. Sci.-China, 46, 321328, https://doi.org/10.1080/00288233.2003.9513560, 2003 (in Chinese).

Sun, D. C., Li, Y. L., Zhao, X. Y., Zuo, X. A., and Mao, W.: Effects of enclosure and grazing on carbon and water 
fluxes of sandy grassland, Chinese J. Plant Ecol., 39, 565-576, https://doi.org/10.17521/cjpe.2015.0054, 2015 (in Chinese).

Suyker, E. A., Verma, S. B., and Burba, G. G.: Inter-annual variability in net $\mathrm{CO}_{2}$ fluxes exchange of a native tallgrass prairie, Glob. Change Biol., 9, 255-265, https://doi.org/10.1046/j.13652486.2003.00567.x, 2003.

Tang, J. W., Baldocchi, D. D., and Xu, L. K.: Tree photosynthesis modulates soil respiration on a diurnal time scale, Glob. Change Biol., 11, 1298-1304, https://doi.org/10.1111/j.13652486.2005.00978.x, 2005.

Ueyama, M., Ichii, K., Hirata, R., Takagi, K., Asanuma, J., Machimura, T., Nakai, Y., Ohta, T., Saigusa, N., Takahashi, Y., and Hirano, T.: Simulating carbon and water cycles of larch forests in East Asia by the BIOME-BGC model with AsiaFlux data, Biogeosciences, 7, 959-977, https://doi.org/10.5194/bg-7959-2010, 2010.

Wagle, P. and Kakani, V. G.: Environmental control of daytime net ecosystem exchange of carbon dioxide in switchgrass, Agr. Ecosyst. Environ., 186, 170-177, https://doi.org/10.1016/j.agee.2014.01.028, 2014.

Wang, X. M., Dong, Z. B., Yan, P., Zhang, J. Z., and Qian, G. Q.: Wind energy environments and dunefield activity in the Chinese deserts, Geomorphology, 65, 33-48, https://doi.org/10.1016/j.geomorph.2004.06.009, 2005.

Webb, E. K., Pearman, G. I., and Leuning, R.: Correction of flux measurements for density effects due to heat and water vapor transfer, Q. J. Roy. Meteor. Soc., 106, 85-100, https://doi.org/10.1002/qj.49710644707, 1980,

Webb, W., Szarek, S., Lauenroth, W., Kinerson, R., and Smith, M.: Primary productivity and water use in native forest, grassland, and desert ecosystem, Ecology, 59, 1239-1247, https://doi.org/10.2307/1938237, 1978.

Wohlfahrt, G., Fenstermaker, L. F., and Arnone III, J. A.: Large annual net ecosystem $\mathrm{CO}_{2}$ uptake of a Mojave Desert ecosystem, Global Change Biol., 14, 1475-1487, https://doi.org/10.1111/j.1365-2486.2008.01593.x, 2008.

Wolf, S., Keenan, T. F., Fisher, J. B., Baldocchi, D. D., Desai, A. R., Richardson, A.D., Scott, R. L., Law, B. E., Litvak, M. E., Brunsell, N. A., Peters, W., and Laan-Luijkx, I. T.: Warm spring reduced carbon cycle impact of the 2012 US summer drought, P. Natl. Acad. Sci. USA, 113, 5880-5885, https://doi.org/10.1073/pnas.1519620113, 2016.

Wu, C. Y., Chen, J. M., Pumpanen, J., Cescatti, A., Marcolla, B., Blanken, P. D., Ardö, J., Tang, Y. H., Magliulo, V., Georgiadis, T., Soegaard, H., Cook, D. R., and Harding, R. J.: An underestimated role of precipitation frequency in regulating summer soil moisture, Environ. Res. Lett., 7, 024011, https://doi.org/10.1088/1748-9326/7/2/024011, 2012.

Wu, X., Yao, Z. N., Brüggemann, N., and Shen, Z. Y.: Effects of soil moisture and temperature on $\mathrm{CO}_{2}$ and $\mathrm{CH}_{4}$ soil atmosphere exchange of various land use/cover types in a semi-arid grassland in Inner Mongolia, China, Soil Biol. Biochem., 42, 773787, https://doi.org/10.1016/j.soilbio.2010.01.013, 2010.
Xu, L. K. and Baldocchi, D. D.: Seasonal variation in carbon dioxide exchange over a Mediterranean annual grassland in California, Agr. Forest Meteorol., 123, 79-96, https://doi.org/10.1016/j.agrformet.2003.10.004, 2004.

Yan, C. Z., Wang, Y. M., Feng, Y. S., and Wang, J. H.: Macroscale survey and dynamic studies of sandy land in Ningxia by remote sensing, J. Desert Res., 23, 34-37, available at: http: //www.desert.ac.cn/CN/Y2003/V23/I2/132 (last access: 10 December 2020), 2003 (in Chinese).

Yun, H., Wu, Q., Zhuang, Q., Chen, A., Yu, T., Lyu, Z., Yang, Y., Jin, H., Liu, G., Qu, Y., and Liu, L.: Consumption of atmospheric methane by the Qinghai-Tibet Plateau alpine steppe ecosystem, The Cryosphere, 12, 2803-2819, https://doi.org/10.5194/tc-122803-2018, 2018.

Zhang, B. W., Li, S., Chen, S. P., Ren, T. T., Yang, Z. Q., Zhao, H. L., Liang, Y., and Han, X. G.: Arbuscular mycorrhizal fungi regulate soil respiration and its response to precipitation change in a semiarid steppe, Sci. Rep.-UK, 6, 19990, https://doi.org/10.1038/srep19990, 2016.

Zhao, H. L., Li, Y. Q., and Zhou, R. L.: Effects of desertification on $\mathrm{C}$ and $\mathrm{N}$ storages in grassland ecosystem on Horqin sandy land, Chinese J. Appl. Ecol., 18, 2412, available at: http://www.cjae. net/CN/Y2007/V18/I11/2412 (last access: 10 December 2020), 2007 (in Chinese).

Zhao, W. Z. and Liu, B.: The response of sap flow in shrubs to rainfall pulses in the desert region of China. Agr. Forest Meteorol., 150, 1297-1306, https://doi.org/10.1016/j.agrformet.2010.05.012, 2010.

Zhao, W. Z. and Liu, H.: Precipitation pulses and ecosystem responses in arid and semiarid regions: a review, Chinese J. Appl. Ecol., 22, 243-249, https://doi.org/10.3724/SP.J.1011.2011.00197, 2011 (in Chinese).

Zhao, X. Y., Wang, S. K., Luo, Y. Y., Huang, W. D., Qu, H., and Lian, J.: Toward sustainable desertification reversion: a case study in Horqin Sandy Land of northern China, Sciences in Cold and Arid Regions, 1, 23-28, available at: http://en.cnki.com.cn/ Article_en/CJFDTOTAL-HAQK201501005.htm (last access: 11 December 2020), 2015.

Zhao, Y. L., Song, Z. L., Xu, X. T., Li, Z. M., Guo, F. S., and Pan, W. J.: Nitrogen application increases phytolith carbon sequestration in degraded grasslands of North China, Ecol. Res., 31, 117-123, https://doi.org/10.1007/s11284-015-1320-0, 2016.

Zhou, Y. Y., Li, X. R., Gao, Y. H., He, M. Z., Wang, M. M., Wang, Y. L., Zhao, L. N., and Li, Y. F.: Carbon fluxes response of an artificial sand-binding vegetation system to ainfall variation during the growing season in the Tengger Desert, J. Environ. Manage., 266, 110556, https://doi.org/10.1016/j.jenvman.2020.110556, 2020. 